\title{
Distinct basin-scale-distributions of aluminum, manganese, cobalt, and lead in the North Pacific Ocean
}

\author{
$\operatorname{AUTHOR}(\mathrm{S})$ : \\ Zheng, Linjie; Minami, Tomoharu; Konagaya, \\ Wataru; Chan, Cheuk-Yin; Tsujisaka, Makoto; \\ Takano, Shotaro; Norisuye, Kazuhiro; Sohrin, \\ Yoshiki
}

\section{CITATION:}

Zheng, Linjie ...[et al]. Distinct basin-scale-distributions of aluminum, manganese, cobalt, and lead in the North Pacific Ocean. Geochimica et Cosmochimica Acta 2019, 254: 102121

\section{ISSUE DATE:}

2019-06-01

URL:

http://hdl.handle.net/2433/241780

\section{RIGHT:}

(c) 2019 This manuscript version is made available under the CC-BY-NC-ND 4.0 license

http://creativecommons.org/licenses/by-nc-nd/4.0/; The full-text file will be made open to the public on 1 June 2021 in accordance with publisher's 'Terms and Conditions for Self-Archiving'; この論文は出版社版でありません。引用の際に は出版社版をご確認ご利用ください。; This is not the published version. Please cite only the published version. 
1 Distinct basin-scale-distributions of aluminum, manganese, cobalt, and lead in the North

2 Pacific Ocean

3

4 Linjie Zheng a, Tomoharu Minami ${ }^{\text {a,b }}$, Wataru Konagaya ${ }^{a}$, Cheuk-Yin Chan ${ }^{a}$, Makoto 5 6

*Corresponding author: Y. Sohrin. E-mail address: sohrin@scl.kyoto-u.ac.jp

Abstract

Aluminum ( $\mathrm{Al})$, manganese $(\mathrm{Mn})$, cobalt $(\mathrm{Co})$, and lead $(\mathrm{Pb})$ are key trace elements in seawater and thus significant in chemical oceanography research. However, although all of these elements are highly scavenged in the ocean, only a few studies focus on the intercomparison of their distributions. Here, we report the basin-scale and full-depth sectional distributions of these elements observed during three GEOTRACES Japan cruises in the North Pacific. We confirmed that a surface maximum of the dissolved (d) species is not a common feature for the four elements and that the $\mathrm{d}$ species have the lowest concentrations in the Pacific Deep Water (PDW) as compared to other oceans. The elements showed different speciations and distributions. The fraction of labile particulate (lp) species was calculated as the difference between the total dissolvable (td) species and $\mathrm{d}$ species. The $1 \mathrm{pM} / \mathrm{tdM}$ ratio, where $\mathrm{M}$ refers to an element, is highest for $\mathrm{Al}$, at $0.66 \pm 0.31$ (average $\pm \mathrm{sd}, n=489$ ), and lowest for $\mathrm{Pb}$, at $0.02 \pm 0.08(n=575)$. Further, the distribution of each element is uniquely related to ocean circulation. The $\operatorname{tdAl}$ concentration is high in the Equatorial Under Current (EUC), the North Equatorial Current (NEC), and the Lower Circumpolar Deep Water 
30 (LCDW). Manganese is supplied from reductive sources such as sediments on the continental 31 shelves around the northern boundary. Cobalt is concentrated in the North Pacific Intermediate Water (NPIW) and in the Equatorial Pacific Intermediate Water (EqPIW) owing to the combined effects of supply from the continental shelves, biogeochemical cycling, and scavenging. Lead shows a subsurface maximum centered at $\sim 35^{\circ} \mathrm{N}$ and $\sim 200 \mathrm{~m}$ depth, implying an association with the formation of the Subtropical Mode Water (SMW) and the Central Mode Water (CMW). Although the subsurface $\mathrm{Pb}$ maximum in the Atlantic has diminished over the last three decades owing to the ban on leaded gasoline use, it has been sustained in the North Pacific through the growth of other anthropogenic sources in Asia and Russia. We propose that the enrichment factor of $\mathrm{dM}$, defined as $E F(\mathrm{dM})=$ $(\mathrm{dM} / \mathrm{dAl})_{\text {seawater }} /(\mathrm{M} / \mathrm{Al})_{\text {upper crust, }}$ where $(\mathrm{M} / \mathrm{Al})_{\text {upper crust }}$ is the molar ratio in upper crustal abundance, can be a good parameter for the sources. The median is $1.3 \times 10^{2}(n=436)$ for $E F(\mathrm{dMn}), 3.2 \times 10^{2}(n=430)$ for $E F(\mathrm{dCo})$, and $1.2 \times 10^{3}(n=413)$ for $E F(\mathrm{dPb})$. The $E F(\mathrm{dPb})$ found in this study is on the same order of magnitude as the $E F$ values for aerosols found in the literature, suggesting that the deposition of aerosols is a major source for $\mathrm{dPb}$. Because $E F(\mathrm{dMn})$ and $E F(\mathrm{dCo})$ are ten to hundred times higher than the $E F$ for aerosols, sources other than the aerosol deposition are more significant contributors to the concentrations of Mn and Co.

Keywords: GEOTRACES; Trace metals; Ocean sections; Scavenging; Biogeochemical cycling; Anthropogenic pollution

\section{INTRODUCTION}

Elements in seawater have been divided into conservative, nutrient (or recycled), and scavenged groups based on their dissolved (d) concentration-depth profiles (Bruland and

56 Lohan, 2003; Chester, 2000). Scavenged group elements are adsorbed on particles and removed from the ocean with a short residence time of $\sim 10^{2}-10^{3}$ years, resulting in high 
$(\mathrm{Co})$, and lead $(\mathrm{Pb})$ are classified as the scavenged elements.

Aluminum is supplied to the ocean surface via the deposition of atmospheric dust (Hydes, 1979; Maring and Duce, 1987). The surface dAl concentration in the Pacific is as low as a tenth of that in the tropical and subtropical North Atlantic, because the Pacific receives less dust per unit area (Bruland et al., 1994; Measures et al., 2005; Measures and Vink, 2000; Orians and Bruland, 1986). Another important transporter of $\mathrm{Al}$ is currents, particularly in the equatorial Pacific (Kaupp et al., 2011; Slemons et al., 2012). Dissolved and particulate Al are transported eastward by the Equatorial Under Current (EUC) from the northeastern coastal margins of New Guinea and New Ireland (Kaupp et al., 2011; Slemons et al., 2012). Supply of Al by tropical and subtropical currents is also observed in the Indian Ocean (Vu and Sohrin, 2013). Other examples would be dAl in Mediterranean Outflow Water (MOW) (Kramer et al., 2004) and in North Atlantic Deep Water (NADW) (Middag et al., 2015). Dissolved Al is removed from the water column by passive adsorption onto particles or active uptake (e.g. diatoms) (Mackenzie et al., 1978; Moran and Moore, 1988). Gehlen et al. (2002) reported direct evidence for the structural association of $\mathrm{Al}$ and silicon ( $\mathrm{Si}$ ) in biogenic silica. The vertical profiles of $\mathrm{dAl}$ in the ocean often exhibit a mid-depth minimum and increasing concentrations towards the sediment-water interface, which is caused by the advection of Al-rich deep water or by the diffusion of $\mathrm{Al}$ from sediment pore water (Bruland et al., 1994; Orians and Bruland, 1985, 1986; Zheng et al., 2017). Suspended particulate Al (pAl) in seawater decreases with distance from the North American continent and increases closer to the bottom due to the resuspension of sediments (Orians and Bruland, 1986). As a result of scavenging, the deep-water $\mathrm{dAl}$ concentration in the North Pacific is $\sim 40$-fold lower than that in the North Atlantic (Orians and Bruland, 1986). Recent GEOTRACES studies have revealed wide variations in the concentration of $\mathrm{dAl}$ and $\mathrm{pAl}$ in both the intra- and inter-basin scales in the Atlantic Ocean (Barrett et al., 2015; Measures et al., 2015; Middag et al., 2015), the Southern Ocean (Middag et al., 2011b), and the Mediterranean Sea (Rolison et al., 2015).

The dMn commonly has a maximum concentration at the surface and in the oxygen minimum layer, where $\mathrm{O}_{2}$ falls below $100 \mu \mathrm{mol} \mathrm{kg}{ }^{-1}$ (Boyle et al., 2005; Bruland et al., 1994; Fujishima et al., 2001; Klinkhammer and Bender, 1980; Landing and Bruland, 1980; Martin 
and Knauer, 1980; Zheng et al., 2017). Manganese maxima also occur in hydrothermal plumes in deep water (Boyle et al., 2005; Coale et al., 1991; Klinkhammer, 1980) and in bottom water at the continental margins (Biller and Bruland, 2013; Chase et al., 2005; Minakawa et al., 1998; Slemons et al., 2012). These dMn maxima are related to reductions of $\mathrm{Mn}(\mathrm{IV})$ or $\mathrm{Mn}(\mathrm{III})$ to soluble $\mathrm{Mn}(\mathrm{II})$. Manganese(IV) is reduced via photoreduction in surface water (Sunda and Huntsman, 1988), by microorganisms in sediments (Froelich et al., 1979), and by seawater-basalt interaction during hydrothermal circulation (Von Damm and Bischoff, 1987). Horizontal sections off of North America indicate that Mn is actively remobilized from anoxic sediments on the continental shelves and slopes, diffused into the overlying seawater, and transported by lateral advection (Jones and Murray, 1985; Martin and Knauer, 1984; Martin et al., 1985). Oxidation of $\mathrm{Mn}(\mathrm{II})$ is microbially catalyzed, resulting in fast scavenging from a water column (Cowen et al., 1990; Mandernack et al., 1995; Moffett and Ho, 1996). Recent GEOTRACES investigations revealed sectional distributions of $\mathrm{Mn}$ in the Atlantic Ocean (Noble et al., 2012; van Hulten et al., 2017), in the Southern Ocean (Middag et al., 2011a), and in the Indian Ocean (Vu and Sohrin, 2013).

The profile of dCo was first observed off central California, showing a surface maximum and a strong correlation with dMn (Knauer et al., 1982). Subsequent observations revealed a subsurface dCo maximum at 50-700 m depths (Ezoe et al., 2004; Fujishima et al., 2001; Noble et al., 2008; Zheng et al., 2017). Cobalt is microbially co-oxidized with Mn (Moffett and Ho, 1996), concentrated in manganese oxides, and released into water through manganese reduction (Biller and Bruland, 2013). Recent studies have indicated the correlation between $\mathrm{dCo}$ and phosphate in the upper water column, concluding that $\mathrm{dCo}$ is affected by both nutrient cycling and scavenging onto manganese oxides (Hawco et al., 2018; Noble et al., 2008; Saito et al., 2017). The latter process concentrates Co in pelagic sediments, manganese nodules, and manganese crusts, resulting in a small $\mathrm{d}$ inventory in deep waters.

Nozaki et al. (1976) reported that radioactive ${ }^{210} \mathrm{~Pb}\left(t_{1 / 2}=22.3 \mathrm{y}\right)$ in the Pacific surface water has a maximum concentration at $\sim 35^{\circ} \mathrm{N}$ and $170^{\circ} \mathrm{E}$. They explained ${ }^{210} \mathrm{~Pb}$ distribution by dust deposition from the atmosphere and scavenging in the water column, estimating the residence time of $\mathrm{Pb}$ in surface water to be 1.7 years in the North Pacific 
117 subtropical gyre. Then, Nozaki et al. (1997) evaluated the residence time of ${ }^{210} \mathrm{~Pb}$ in the

118 Pacific Deep Water (PDW) to be $>200$ years in the central gyre and 50-100 years at the 119 margins. For stable $\mathrm{Pb}$, Schaule and Patterson (1981) studied the concentration of total 120 dissolvable $\mathrm{Pb}(\mathrm{tdPb})$ in seawater between Hawaii and California, revealing the first reliable 121 vertical profile of stable $\mathrm{Pb}$ in 1976. Lead is supplied to the North Pacific mainly via the atmosphere at a rate of $\sim 50 \mathrm{ng} \mathrm{cm} \mathrm{c}^{-2}$, which exceeds the prehistoric output flux of authigenic $\mathrm{Pb}$ recorded in pelagic sediments by $\sim 170$ times (Flegal and Patterson, 1983). Both

124 the ${ }^{206} \mathrm{~Pb} /{ }^{207} \mathrm{~Pb}$ and ${ }^{206} \mathrm{~Pb} /{ }^{208} \mathrm{~Pb}$ ratios in seawater fitted between the isotopic ratios of Australian and North American leads (Flegal et al., 1984). Boyle et al. (2005) reported a tdPb profile at the Hawaii Ocean Time-series (HOT)-A Long-Term Oligotrophic Habitat Assessment (ALOHA) station $\left(22.75^{\circ} \mathrm{N}, 158^{\circ} \mathrm{W}\right)$ in 1999 and found an insignificant change in the subsurface maximum concentration from that in 1976. They attributed the remaining $\mathrm{Pb}$ in the Pacific water to Asian emissions by high-temperature processes such as coal burning, although leaded gasoline had been abolished in the United States, Canada, and Japan. They also observed a time-series in the mixed layer near the Hawaii Air-Sea Logging Experiment (HALE)-ALOHA mooring site and reported the presence of an annual cycle in the $\mathrm{Pb}$ concentration in which it is $\sim 20 \%$ higher in the winter months owing to the downward mixing of the winter mixed layer. Wu et al. (2010) reported that the ${ }^{206} \mathrm{~Pb} /{ }^{207} \mathrm{~Pb}$ ratio in the North Pacific abyssal water is substantially lower than the pre-industrial value, suggesting that anthropogenic $\mathrm{Pb}$ has invaded and become the predominant $\mathrm{Pb}$ source there. Recently, comprehensive data on $\mathrm{Pb}$ isotopes in seawater have been reported from the western North

138 Pacific (Gallon et al., 2011; Zurbrick et al., 2017). It was concluded that only three 139 countries - China, Russia, and Japan - have aerosol $\mathrm{Pb}$ isotope composition similar to that of 140 seawater and these occupy about $74 \%$ of the industrial input to the western North Pacific. The 141 latest data on the distribution of $\mathrm{Pb}$ in seawater were obtained from the Philippine Sea (Chien 142 et al., 2017), near the Juan de Fuca Ridge (Zheng et al., 2017), and from the eastern equatorial

143 Pacific (Pinedo-González et al., 2018). Sectional distributions of $\mathrm{Pb}$ have been reported in the 144 Atlantic Ocean (Bridgestock et al., 2018; Bridgestock et al., 2016; Noble et al., 2015; Rigaud et al., 2015; Rusiecka et al., 2018; Zurbrick et al., 2018) and the Indian Ocean (Echegoyen et 
al., 2014; Lee et al., 2015; Vu and Sohrin, 2013).

These results suggest that $\mathrm{Al}, \mathrm{Mn}, \mathrm{Co}$, and $\mathrm{Pb}$ are strongly controlled by scavenging. However, each element has specific effects such as supply from reductive sources for Mn and $\mathrm{Co}$, nutrient cycling for $\mathrm{Co}$, and anthropogenic contamination for $\mathrm{Pb}$. Simultaneous observation of these elements will serve to understand these specific effects. Studies conducting such observations are, however, limited, owing to challenges to analysis (Zheng et al., 2017). Here, we report the basin-scale and full-depth sectional distributions of $\mathrm{Al}, \mathrm{Mn}, \mathrm{Co}$, and $\mathrm{Pb}$ in the North Pacific for the first time. We observed the distributions of both $\mathrm{td}$ and $\mathrm{d}$ species of these elements using a multielement analytical method (Minami et al., 2015) without ultraviolet (UV) irradiation during three GEOTRACES Japan cruises. The difference between $t d$ and $d$ concentrations is defined as the labile particulate (lp) concentration. The $1 p$ species are liberated from particulate phases during sample storage at $\mathrm{pH} \sim 2$ with added $\mathrm{HCl}$ and at room temperature for more than one year. On the basis of the comprehensive dataset, we systematically discuss the biogeochemical cycling of the scavenged elements in the North Pacific.

\section{METHODS}

\subsection{Hydrographic background of the study site}

This study was conducted on the following cruises of R/V Hakuho Maru: KH-05-2 from August to September 2005, KH-11-7 in July 2011, and KH-12-4 from August to September 2012 (Fig. 1). The map and a number of figures in this paper were prepared using the Ocean Data View software (Schlitzer, 2018). The KH-05-2 cruise was a reconnaissance study by GEOTRACES Japan. KH-11-7 and KH-12-4 were formal studies by GEOTRACES Japan, occupying GEOTRACES sections GP18 $\left(165^{\circ} \mathrm{E}\right)$ and GP02 $\left(47^{\circ} \mathrm{N}\right)$, respectively. Figure 2 shows the full-depth sectional distributions of salinity, $\mathrm{O}_{2}$, silicate, phosphate, and tdM along $160^{\circ} \mathrm{W}$ longitude. The data from $165^{\circ} \mathrm{E}$ and $47^{\circ} \mathrm{N}$ are shown in Supplementary Figs. 1 and 2, respectively. Supplementary Figs. 3 and 4 show the sectional distributions of salinity, potential temperature, $\mathrm{O}_{2}$, silicate, and phosphate at depths of $0-1000 \mathrm{~m}$ along 
175

176

177

178

179

180

181

182

183

184

185

186

187

188

189

190

191

192

193

194

195

196

197

198

199

200

201

202

203

$160^{\circ} \mathrm{W}$ and $165^{\circ} \mathrm{E}$, respectively.

In the tropical Pacific, three major zonal surface currents exist (Fig. 1): the westward-flowing South Equatorial Current (SEC) between about $20^{\circ} \mathrm{S}$ and $3^{\circ} \mathrm{N}$ (ST01-03), the narrow eastward-flowing North Equatorial Counter Current (NECC) centered at about $5^{\circ} \mathrm{N}$ (ST04, 05), and the westward-flowing North Equatorial Current (NEC) between about $8^{\circ} \mathrm{N}$ and $20^{\circ} \mathrm{N}(\mathrm{ST06}, 07)$ (Wyrtki and Kilonsky, 1984). The EUC is fed by the saline New Guinea Coastal Under Current and flows eastward just below the SEC within a pycnocline at about 200 m depth at ST03 (Supplementary Fig. 3a).

The westward-flowing NEC forms the southern side of the anticyclonic North Pacific subtropical gyre (Fig. 1), splitting into northward and southward boundary currents known as the Kuroshio and Mindanao Currents, respectively. The Kuroshio turns to follow the south coast of Japan and flows eastward at about $35^{\circ} \mathrm{N}$ to become the Kuroshio Extension (KE), which forms the northern side of the subtropical gyre (Fig. 1). The KE region is between about $30^{\circ} \mathrm{N}$ and $40^{\circ} \mathrm{N}$ (TR07-09), where surface water is characterized by high salinity $>34.3$ and high temperature $>15^{\circ} \mathrm{C}$. Water masses beneath the surface water include the Subtropical Mode Water (STMW) and the Central Mode Water (CMW) with potential density anomaly $\left(\sigma_{\theta}\right)$ values of 25.2-25.8 and 26.0-26.4, respectively (Yasuda, 2003) (Supplementary Fig. 4a). The formation region of the STMW is located at $32-35^{\circ} \mathrm{N}$, $140-180^{\circ} \mathrm{E}$, and the formation region of CMW is located at $36-43^{\circ} \mathrm{N}, 150^{\circ} \mathrm{E}-160^{\circ} \mathrm{W}$. The region between the Kuroshio and the Oyashio is referred to as the Transition Region (TR11, ST11, 12; Fig. 1). The broad eastward flow of this region, known as the North Pacific Current (NPC), includes both the northern side of the subtropical gyre and the southern side of the cyclonic subarctic gyre. At the eastern boundary, the NPC feeds into the southward-flowing California Current (BD17-18) and the northward-flowing Alaska Current.

The western boundary current for the North Pacific subpolar gyre is the Oyashio/East Kamchatka Current (EKC; Fig. 1). The Oyashio separates from the western boundary at about $42^{\circ} \mathrm{N}$ and flows northeastward as the Oyashio Extension (OE), where surface water is characterized by salinity of $32.7-33.8$ and temperature of $0.9-11.1^{\circ} \mathrm{C}$ (TR13). The subsurface water is the Okhotsk Sea Mode Water (OSMW), at 26.6-27.0 $\sigma_{\theta}$, which 
originates in the Sea of Okhotsk and flows out to the Pacific through the Kuril Straits (Yasuda, 1997). The OSMW is observed at a depth of about $200 \mathrm{~m}$ at TR16/BD07 (Supplementary Fig. 4a). A number of northern stations in this study (TR15, 16, BD07-16, ST13) are located within the subpolar gyre (Fig. 1). The northern side of the gyre is the westward-flowing Alaskan Stream (AS; ST14).

The North Pacific Intermediate Water (NPIW) and the Antarctic Intermediate Water (AAIW) are well-known intermediate water masses in the Pacific Ocean (Talley et al., 2011). Recently, a third main water type at intermediate depths was proposed: the Equatorial Pacific Intermediate Water (EqPIW) (Bostock et al., 2010). The NPIW, which is characterized by a salinity minimum of 33.8 , low $\mathrm{O}_{2}$ at $50-150 \mu \mathrm{mol} \mathrm{kg}{ }^{-1}$, and low density of $26.4-27.2 \sigma_{\theta}$, averaging $26.8 \sigma_{\theta}$, originates from the OSMW (Yasuda, 1997). The NPIW spreads over the subtropical gyre at a depth range of 400-800 m, bounded by the subarctic front to the north at $\sim 40^{\circ} \mathrm{N}$ (ST11) and a steep potential vorticity gradient to the south at $15-20^{\circ} \mathrm{N}$ (ST07; Fig. 2a and Supplementary Fig. 3a). The AAIW is a distinct water mass with high $\mathrm{O}_{2}$ concentrations of $200-250 \mu \mathrm{mol} \mathrm{kg}$, salinity minima of $34.3-34.5$, and a temperature range of $3.5-10^{\circ} \mathrm{C}$, resulting in an average density of $27.1 \sigma_{\theta}$. The AAIW forms below the subantarctic front and is then subducted along an isopycnal surface at depths of $600-1300 \mathrm{~m}$. The EqPIW is characterized by low $\mathrm{O}_{2}$ on the 26.8-27.2 $\sigma_{\theta}$ isopycnals (ST01-06; Fig. 2a and Supplementary Fig. 3a). The geochemistry of the EqPIW suggests that it is composed primarily of a combination of AAIW and upwelled PDW (Bostock et al., 2010).

In the deep ocean, the Lower and Upper Circumpolar Deep Waters (LCDW and UCDW, respectively) are transported to the North Pacific from the Antarctic Circumpolar Current (Fig. 2c). The LCDW is characterized by a temperature range of $1-2^{\circ} \mathrm{C}$, salinity of 34.7, density of $27.8 \sigma_{\theta}$, and the salinity maximum (Talley et al., 2011). The UCDW is characterized by a temperature of $2.5^{\circ} \mathrm{C}$, salinity of 34.6 , density of $27.6 \sigma_{\theta}$, and the $\mathrm{O}_{2}$ minimum. The LCDW enters the Central Pacific Basin through the Samoan Passage, proceeds farther north, and reaches the Northeast Pacific Basin (Kawabe and Fujio, 2010) (Fig. 4a). The major branch flows anticyclonically along the Japan, Kuril-Kamchatka, and Aleutian Trenches. The LCDW finally upwells and is transformed into the PDW, which is 
internally formed entirely in the Pacific from the upwelling and diffusion of the LCDW. The PDW has physical properties similar to those of the UCDW but is enriched with nutrients. It shifts southward in the upper deep layer and is modified by mixing with the UCDW around the Hawaiian Islands (Fig. 2c).

\subsection{Sampling and analysis}

Seawater samples were collected during the three GEOTRACES Japan cruises (KH-05-2, KH-11-7, and KH-12-4) using a clean sampling system (Sohrin and Bruland, 2011). The system was based on a Carousel Water Sampler Frame (SBE-32, Sea-Bird Scientific, USA) that was finished with epoxy paint and equipped with conductivity, temperature, and depth (CTD) sensors (SBE-9-plus, Sea-Bird) and Niskin-X bottles (General Oceanics, USA). The insides of the Niskin bottles were coated with Teflon and were cleaned

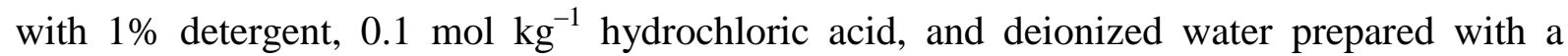
Milli-Q system (MQW; Merck Millipore, Germany) at the beginning of the cruises. The clean sampling system was deployed using a titanium-armored cable. Seawater temperature was measured with the CTD sensor. Salinity reported in this paper was determined using a bench salinometer that was standardized on the basis of the IAPSO standard seawater; the $\mathrm{O}_{2}$ content was measured using the Winkler method; and nutrient concentrations were determined by spectrophotometry using an automated analyzer onboard the vessel. These measurements were in accordance with the protocols for JGOFS (Knap et al., 1996). Nutrient data were checked using seawater reference nutrient material (KANSO, Japan).

During KH-05-2, seawater was transferred from the sampler to precleaned Nalgene low-density polyethylene (LDPE) bottles (Thermo Fisher Scientific, USA) on deck using a silicon tube and filling bell to avoid contamination by airborne particles. The samples were immediately transferred into a cleanroom laboratory (class 100) on the vessel. A portion of the seawater for dissolved metal $(\mathrm{dM})$ species was passed through a polycarbonate Nuclepore filter with a pore size of $0.2 \mu \mathrm{m}$ and a diameter of $47 \mathrm{~mm}$ (Whatman, UK) using a closed filtration system. The filter was precleaned with mixtures of $\mathrm{HCl}-\mathrm{H}_{2} \mathrm{O}_{2}$ and $\mathrm{HCl}-\mathrm{HNO}_{3}-\mathrm{HF}$ (Nakatsuka et al., 2007). The filtered seawater was acidified to $\mathrm{pH} 2.2$ with ultrapure $\mathrm{HCl}$ 
262 (Tamapure AA-10, Tama Chemicals, Japan). The portion of the seawater for total dissolvable 263 metal (tdM) species analysis was acidified without filtration. These samples were stored at 264 ambient temperature for $\sim 10$ years before analysis.

During KH-11-7 and KH-12-4, the Niskin bottles were carried into a clean bubble upon retrieval of the CTD sampling system, and the seawater samples were transferred from the Niskin bottles to precleaned LDPE bottles. During KH-11-7, filtration was conducted using a Nuclepore filter in a manner similar to that used during KH-05-2. During KH-12-4, filtration was conducted using an AcroPak capsule filter with a pore size of $0.2 \mu \mathrm{m}$ (Pall, USA), which was directly attached to the Niskin bottle. The seawater samples for both $\mathrm{d}$ and td species analyses were immediately acidified in a manner similar to that used during KH-05-2 and were stored at ambient temperature for at least one year before analysis.

An off-line automated solid-phase extraction system (SPE-100, Hiranuma Sangyo, Japan) equipped with a column of Nobias Chelate-PA1 resin (Hitachi High Technologies, Japan) was used for the preconcentration of $\mathrm{Al}, \mathrm{Mn}$, iron $(\mathrm{Fe})$, Co, nickel $(\mathrm{Ni})$, copper $(\mathrm{Cu})$, zinc $(\mathrm{Zn})$, cadmium $(\mathrm{Cd})$, and $\mathrm{Pb}$ from the seawater (Minami et al., 2015). The seawater samples were adjusted to $\mathrm{pH} 6.00 \pm 0.05$ just before preconcentration by adding $\mathrm{HAcO}-\mathrm{NH}_{4} \mathrm{AcO}$ buffer solution prepared from ultrapure $\mathrm{HAcO}$ and $\mathrm{NH}_{3}$ (TAMAPURE AA-10 or Optima Acids, Thermo Fisher Scientific). When preconcentrating the tdM species, unfiltered samples were first passed through a Millex syringe filter with a pore size of 0.45 $\mu \mathrm{m}$ (Merck Millipore, Germany) and then introduced into the SPE-100. The nine metals were eluted with $1.0 \mathrm{~mol} \mathrm{~kg}{ }^{-1} \mathrm{HNO}_{3}$ (Optima Acids) and determined with a high-resolution inductively coupled plasma mass spectrometer (HR-ICP-MS, Element 2, Thermo Fisher Scientific) using a calibration curve.

It has been reported that UV irradiation prior to preconcentration is necessary for analysis of total dCo (Biller and Bruland, 2012; Milne et al., 2010; Saito and Moffett, 2001).

287 The UV irradiation is adopted in the Sampling and Sample-handling Protocols for the 288 GEOTRACES Cruises. However, we refrained from using UV irradiation to minimize 289 contamination of the nine metals and to avoid unknown effects of UV irradiation on the determination of the nine metals. So far, we have done two runs of experiment to investigate 
the effect of UV irradiation on the determination of the nine metals. A portion of the surface

292 seawater sample collected from the North Pacific was taken in a PFA jar with a quartz 293 window and exposed to a $20 \mathrm{~mW} \mathrm{~cm} \mathrm{~cm}^{-2}$ lamp for 2-24 h. We found that the concentration of $294 \mathrm{Al}$ and Fe sometimes decreased due to unknown effects of UV irradiation. Recently, Wuttig et al. (2019) studied the effect of UV irradiation and suggested that it should not be performed on samples in which multiple elements are to be determined in order to avoid unnecessary container leaching or contamination. Thus, it should be noted that our Co data are operational results.

We evaluated the procedure blanks by using MQW as a sample. The MQW was initially acidified with $\mathrm{HCl}$ and then adjusted to $\mathrm{pH} 6.00$ for preconcentration, which is a process similar to that used for seawater samples. We detected contamination during the filtration using a Nuclepore filter for KH-05-2 and KH-11-7. To eliminate this effect, a filtration method similar to that used for seawater was applied to MQW for evaluation of the procedure blanks for $\mathrm{dM}$. We defined the detection limits for tdM and $\mathrm{dM}$ as three times the standard deviation (sd) of the procedure blank. The lpM concentrations were obtained by taking the difference between tdM and dM. Because the relative standard deviation (rsd) was $\sim 5 \%$ for both $\mathrm{tdM}$ and $\mathrm{dM}$, the detection limit of $1 \mathrm{pM}$ was defined by using the following equation considering the propagation of uncertainty: $2 \times \sqrt{2} \times 0.05 \times C_{\text {ave }}$, where $C_{\text {ave }}$ represents the average concentration of each $\mathrm{dM}$ in this study. The procedure blanks and detection limits are summarized in Supplementary Table 1. We measured the certified reference materials for the trace metals, CASS-5 and NASS-6 (National Research Council

312 Canada), and GEOTRACES open-ocean reference samples SAFe-D2, GS, and GD at an early 313 point in the study (Minami et al., 2015). We participated in the intercalibration campaign of 314 new reference materials of CASS-6 and NASS-7, contributing to the establishment of 315 certified values at a late point in the study (Yang et al., 2018). Recently, we measured new 316 GEOTRACES reference samples, GSP and GSC1. All of these data ensured the accuracy of 317 the trace metal data collected in this study (Supplementary Table 2). A part of our data (dMn 318 and $\mathrm{dPb}$ from GP02 and GP18) has been accepted for the GEOTRACES Intermediate Data 319 Product 2017 (Schlitzer et al., 2018). The data on $\mathrm{Fe}, \mathrm{Ni}, \mathrm{Cu}, \mathrm{Zn}$, and $\mathrm{Cd}$ will be reported in 
forthcoming papers.

\section{RESULTS}

The seawater data are summarized in Supplementary Table 3. At stations ST01 and 02 of KH-05-2 and TR 07, 11, 13, and 15 of KH-11-7, the vertical profiles of dAl showed abnormal maxima higher than $1 \mathrm{nmol} \mathrm{kg}^{-1}$ at intermediate depths, suggesting that contamination from the filtration system occurred at the beginning of each cruise. The $\mathrm{dPb}$ data at TR07 were also questionable due to the contamination. Some samples showed abnormally high values of both $\mathrm{tdM}$ and $\mathrm{dM}$ concentrations, particularly for $\mathrm{Pb}$, suggesting that contamination occurred during sampling. These questionable data have been removed from the discussion. The summary of the seawater data is presented in Table 1. Figure 2 and Supplementary Figs. 1 and 2 show the full-depth sectional distributions of salinity, $\mathrm{O}_{2}$, silicate, phosphate, and tdM along $160^{\circ} \mathrm{W}, 165^{\circ} \mathrm{E}$ (GEOTRACES section GP18), and $47^{\circ} \mathrm{N}$ (GP02), respectively. Figure 3 and Supplementary Figs. 5 and 6 show sectional distributions of dM and $1 \mathrm{pM}$ for depths of $0-1000 \mathrm{~m}$. The local distributions around the Juan de Fuca Ridge have been reported in a previous paper (Zheng et al., 2017).

3.1. Aluminum

The tdAl concentration was as low as about $1 \mathrm{nmol} \mathrm{kg}^{-1}$ at $40-50^{\circ} \mathrm{N}$, at $0-4000 \mathrm{~m}$ depth in the $160^{\circ} \mathrm{W}$ section (Fig. 2e). It steeply increased up to $60 \mathrm{nmol} \mathrm{kg}{ }^{-1}$ above $50^{\circ} \mathrm{N}$ due to supply from the continental shelf and slop. In the southern deep waters at $>4000 \mathrm{~m}$ depths, an elevated tdAl concentration was observed with a high $\mathrm{O}_{2}$ concentration, suggesting that it was supplied by the LCDW flowing northward from the Southern Ocean. High tdAl concentrations in deep waters were also found to the north of $40^{\circ} \mathrm{N}$, where the LCDW flows eastward (Fig. 4). In the upper section, dAl maxima near $8 \mathrm{nmol} \mathrm{kg}^{-1}$ were located at a depth of $200 \mathrm{~m}$ at the equator, and at the surface at $15-20^{\circ} \mathrm{N}$ (Fig. 3a). They correspond to the EUC and NEC, respectively. In contrast, the supply from the northern boundary was dominated by lpAl (Fig. 3e). 
In the sections along $165^{\circ} \mathrm{E}$ and $47^{\circ} \mathrm{N}$, tdAl was also high below the depth of 4400 m (Supplementary Figs. 1e and 2e). The tdAl species was dominated by lpAl near the 351 Kamchatka Peninsula (Figs. 7a and b), the Aleutian Islands (Fig. 6a and Supplementary Fig. 352 7a), and the Juan de Fuca Ridge (Zheng et al., 2017).

Figures $4 \mathrm{a}$ and $4 \mathrm{~b}$ show the horizontal distribution of tdAl and dAl, respectively, at 354 a depth of $4500 \mathrm{~m}$ where the LCDW flows. Our data are not enough to cover the whole area 355 of the North Pacific. However, it is apparent that the tdAl concentration tends to be high 356 along the main path of LPDW. Some local sources are found near the Hawaiian Islands, off of 357 the Kamchatka Peninsula, and off of the Aleutian Islands. In contrast, the dAl distribution 358 shows a zonal characteristic. The dAl concentration decreases with latitude, suggesting that 359 there are no strong local sources at high latitudes.

3.2. Manganese

The tdMn concentration was uniformly low at $0.2-0.3 \mathrm{nmol} \mathrm{kg}^{-1}$ in deep waters along $160^{\circ} \mathrm{W}$, with an increase of up to $1 \mathrm{nmol} \mathrm{kg}^{-1}$ in the LCDW (Fig. 2f). High tdMn values of up to $12 \mathrm{nmol} \mathrm{kg}^{-1}$ occurred near the continental shelf of the Aleutian Islands. In the upper section, surface maxima of dMn were found in surface water where the SEC and NEC flow (Fig. 3b). Dissolved Mn was as high as $8 \mathrm{nmol} \mathrm{kg}^{-1}$ in surface water at the northernmost station ST14 in the AS, and spreaded downwards along an isopycnic surface of about $27.0 \sigma_{\theta}$. In contrast, a significant lpMn maximum was observed only in surface water at ST14 (Fig. 3f).

Elevated tdMn and dMn concentrations also occurred in surface waters to the north of $45^{\circ} \mathrm{N}$ along $165^{\circ} \mathrm{E}$ (Supplementary Figs. 1f and 5a) and at the western and eastern ends along $47^{\circ} \mathrm{N}$ (Supplementary Figs. $2 \mathrm{f}$ and $6 \mathrm{~b}$ ), suggesting sources on the continental shelves. In addition, high tdMn and dMn concentrations occurred in bottom water at TR16 near the Kamchatka Peninsula (Supplementary Figs. 1f and 2f) and at middle depths of 1780-3700 m around the Juan de Fuca Ridge (Zheng et al., 2017). In deep waters, tdMn was dominated by lpMn and showed a similar distribution with tdAl (Supplementary Figs. 1f and 2f). 
3.3. Cobalt

The concentrations of tdCo and dCo were remarkably high, up to $220 \mathrm{pmol} \mathrm{kg}^{-1}$ in the AS, similar to tdMn and dMn (Figs. $2 \mathrm{~g}$ and $3 \mathrm{c}$ ). Cobalt spreaded much more widely than $\mathrm{Mn}$ in a zone of 26.5-27.0 $\sigma_{\theta}$, where the NPIW and the EqPIW existed. In the upper section, dCo was depleted in surface water from $10^{\circ} \mathrm{S}$ to $40^{\circ} \mathrm{N}$ in contrast with dMn, suggesting uptake by phytoplankton (Fig. 3c). The lpCo concentration showed some surface maxima along $160^{\circ} \mathrm{W}$ and abrupt increase at the northern boundary (Fig. $3 \mathrm{~g}$ ).

The concentrations of tdCo and dCo were as high as $90 \mathrm{pmol} \mathrm{kg}^{-1}$ in shallow water along the Kamchatka Peninsula and extended along a zone of 26.5-27.0 $\sigma_{\theta}$ (Supplementary Figs. $1 \mathrm{~g}$ and $5 \mathrm{~b}$ ). Along $47^{\circ} \mathrm{N}$, tdCo and dCo showed maxima in surface water at the western and eastern ends, similar to tdMn and dMn (Supplementary Figs. 2g and 6c); however, tdCo and dCo were distributed more uniformly at intermediate depths. The lpCo concentration showed bottom maxima similar to those of lpAl in the three sections, while the maximum lpCo concentration was less than $20 \mathrm{pmol} \mathrm{kg}^{-1}$. A high concentration of $1 \mathrm{pCo}$ was also observed in the bottom water around the Juan de Fuca Ridge, although an increase in dCo was not observed (Zheng et al., 2017).

Figure 5a shows the horizontal distribution of tdCo along the isopycnal surface of $26.8 \sigma_{\theta}$. It appears that tdCo has sources on continental shelves and spreads up to the equatorial Pacific. A similar figure for tdMn indicates the same continental shelf sources for tdMn as tdCo. However, the spreading of tdMn is unclear south of $40^{\circ} \mathrm{N}$.

\subsection{Lead}

The $\mathrm{tdPb}$ concentration was uniformly low at $<24 \mathrm{pmol} \mathrm{kg}^{-1}$ below the depth of $2000 \mathrm{~m}$ along $160^{\circ} \mathrm{W}$ (Fig. $2 \mathrm{~h}$ ). This is similar to that for tdCo. However, tdPb had a unique subsurface maximum between $15^{\circ} \mathrm{N}$ and $50^{\circ} \mathrm{N}$ at $160^{\circ} \mathrm{W}$. The tdPb species were dominated by $\mathrm{dPb}$, and the maxima of $\mathrm{dPb}$, as high as $80 \mathrm{pmol} \mathrm{kg}^{-1}$, occurred in surface water, the STMW, and the CMW (Fig. 3d).

The maxima of $\mathrm{tdPb}$ and $\mathrm{dPb}$ in surface and subsurface water were also apparent south of $42^{\circ} \mathrm{N}$ at $165^{\circ} \mathrm{E}$, which is located above the maxima of tdCo and dCo along the NPIW 
407 (Supplementary Figs. $1 \mathrm{~h}$ and $5 \mathrm{c}$ ). The maxima of $\mathrm{tdPb}$ and $\mathrm{dPb}$ were weaker in the section 408 along $47^{\circ} \mathrm{N}$ (Supplementary Figs. $2 \mathrm{~h}$ and $6 \mathrm{~d}$ ). Labile particulate $\mathrm{Pb}$ was usually undetectable, 409 while it was detected in patches in surface water and in a hydrothermal plume near the Juan 410 de Fuca Ridge (Zheng et al., 2017).

Figure $5 \mathrm{~b}$ shows the horizontal distribution of the maximum $\mathrm{tdPb}$ concentration 412 through the water column. The maximum $\mathrm{tdPb}$ concentration usually occurs at subsurface. 413 The $\mathrm{tdPb}$ maximum decreases and the corresponding $\sigma_{\theta}$ increases from west to east: for 414 example, the tdPb maximum is $89.7 \mathrm{pmol} \mathrm{kg}^{-1}$ at $25.31 \sigma_{0}$, TR7 $\left(165^{\circ} \mathrm{E}\right), 81.6 \mathrm{pmol} \mathrm{kg}^{-1}$ at $25.97 \sigma_{0}, \mathrm{ST} 10\left(160^{\circ} \mathrm{W}\right)$, and $76.9 \mathrm{pmol} \mathrm{kg}^{-1}$ at $26.26 \sigma_{0}, \mathrm{BD} 17\left(132.7^{\circ} \mathrm{W}\right)$.

Table 2 summarizes the metal concentrations in each water mass in the North Pacific Ocean. It is apparent that each metal concentration is uniquely related with the water masses.

\section{DISCUSSION}

4.1. Comparison at crossover stations and with previously published data

In the GEOTRACES program, a crossover station is a location where the track of one cruise overlaps with that of another cruise, although the research vessels do not have to be at the same location simultaneously (http://www.geotraces.org). Concentrations of $\mathrm{dM}$ in the deep ocean are not expected to change significantly on the time scale between cruises; thus, comparing results from crossover stations provides a measure of internal consistency. There are no strict crossover stations between cruises KH-05-2 and KH-12-4. However, stations ST13 and 14 of KH-05-2 are located at about $100 \mathrm{~km}$ and $300 \mathrm{~km}$ from BD15 of KH-12-4 $\left(160^{\circ} \mathrm{W}, 50.8^{\circ} \mathrm{N}\right)$, respectively. Thus, we can use the vertical profiles at these stations for

431 intracomparison. Figure 6 and Supplementary Fig. 7 show the vertical profiles of tdM and dM, respectively, at these stations. For $\mathrm{Mn}$ and $\mathrm{Co}$, the vertical profiles of tdM and $\mathrm{dM}$ were mostly consistent between stations ST13 and BD15. Both tdM and dM showed good linearity

434 with a slope close to unity (Supplementary Fig. 8). These results indicate that no significant 
436 are consistent for Mn and Co. At ST14, significantly higher concentrations of Mn and Co

437 were observed. ST14 is located about $80 \mathrm{~km}$ off the shelf break and above the Aleutian

438 Trench. The high concentrations of Mn and Co in the surface water are supplied by the AS 439 from reductive sources in continental shelf sediments. In deep water of 500-4000 m, Mn and

440 Co are supplied from the continental slope by resuspension of sediments. The distance effect 441 on concentration was most apparent for tdAl (Fig. 6a). A large amount of Al, mostly in lpAl, 442 is supplied from the continental shelf and slope to ST14. Although most of the Al is removed 443 from the water column between ST14 and BD15 by boundary scavenging, the tdAl 444 concentration is still higher at BD15 than at ST13. In contrast, the distance effect was minor 445 for dAl (Supplementary Fig. 7a). A distinct trend was observed for $\mathrm{Pb}$. In deep water, 446 insignificant differences were noted among the three stations in $\mathrm{tdPb}$ and $\mathrm{dPb}$ concentrations 447 (Fig. 6d and Supplementary Fig. 7d). The concentrations in the surface water increased from 448 the north station to the south station, suggesting that lithogenic and reductive sources have a 449 negligible effect on $\mathrm{Pb}$. In addition, no distance effect was noted on the $\mathrm{Pb}$ concentrations in 450 the subsurface maximum at 100-200 m depths. Rather, the subsurface $\mathrm{Pb}$ concentrations are 451 dependent on time, decreasing by about $13 \mathrm{pmol} \mathrm{kg}^{-1}$ from 2005 to 2012.

For KH-11-7 and KH-12-4, stations TR16 and BD07 are occupied at the same position $\left(160^{\circ} \mathrm{E}, 47^{\circ} \mathrm{N}\right)$ as a crossover station. Figure 7 and Supplementary Fig. 9 show the vertical profiles of $\operatorname{tdM}$ and $\mathrm{dM}$ at these stations. Supplementary Fig. 10 shows the relationship of metal concentrations between TR16 and BD07. For $\mathrm{Mn}$, Co, and Pb, the vertical profiles were consistent between the two stations except that the Mn concentrations in the bottom water were higher in 2012 than in 2011. In contrast, both tdAl and dAl were higher in 2011 than in 2012. The same trend was observed for tdFe, which will be reported in the forthcoming paper. We propose a hypothesis that these temporal changes were caused by

460 the earthquake and tsunami. Stations TR16 and BD07 are located about $280 \mathrm{~km}$ southeast of the Kuril-Kamchatka Trench, where the Pacific Plate is subducting under the North American 462 Plate and seismic activity is high. The lower maps in Fig. 7 show the distribution of 463 earthquakes with magnitude $>5$ that occurred for five months prior to the sampling dates during 2011 and 2012 (data taken from https://earthquake.usgs.gov/). No significant 
465 difference is noted in the seismic activity around the Kuril-Kamchatka Trench between the 466 two periods. A clear difference is the March 11, 2011, earthquake off the Pacific coast of 467 Tohoku, Japan, magnitude 9.1 , that occurred at $38.297^{\circ} \mathrm{N}, 142.373^{\circ} \mathrm{E}$ and its aftershocks. The 468 resulting tsunami inundated a total area of $561 \mathrm{~km}^{2}$ in Japan (data from Geospatial 469 Information Authority in Japan: http://www.gsi.go.jp/common/000059939.pdf). The tsunami 470 generated turbidity currents, one of which was observed with bottom sensors (Arai et al., 471 2013). Thirty-six days after the earthquake, observation on the continental slope below the 472 hypocenter revealed increases in the light transmission anomaly and in the Mn concentrations 473 of up to $15-24 \mathrm{nmol} \mathrm{kg}^{-1}$ in the bottom water at depths of 3500-5700 m (Kawagucci et al., 474 2012). Four months after the earthquake, observations in the Japan Trench revealed nepheloid 475 layers extending $\sim 30-50 \mathrm{~m}$ above the sea bed and ${ }^{134} \mathrm{Ce}$ from the Fukushima Daiichi nuclear 476 disaster on the sediment surface (Oguri et al., 2013). Because the distance between the 477 seismic center and TR16 is about $1730 \mathrm{~km}$, the effect might have reached TR16 prior to 478 sampling. The high Mn concentrations in 2012 can be explained by a supply from a temporal reductive source that developed on the bottom sediments where a large amount of organic 480 detritus was transported by the tsunami and the following processes. The detailed explanation 481 of the transportation mechanism is a challenge for future research. Increased marine sediment 482 suspension and fluxes following an earthquake have also been observed at other locations 483 (Thunell et al., 1999).

We also compared our data with the literature and found general consistency for each metal; an example is shown in Supplementary Fig. 11. On the basis of these results, we deduced the following four conclusions. First, the preservation period of the samples had no significant effects on the data. Both unfiltered and filtered seawater samples were acidified to $\mathrm{pH} 2.2$ with $\mathrm{HCl}$ and were stored at room temperature from one to ten years prior to analyses. No effect of the storage period was found for either tdM and $\mathrm{dM}$ at all crossover stations. In addition, a number of samples were analyzed in duplicate without significant changes, 491 depending on the storage period. Thus, we can conclude that both the unfiltered and filtered 492 seawater samples at $\mathrm{pH} 2.2$ are stable for the determination of the trace metals from one to ten 493 years. 
Second, although we did not apply UV irradiation prior to the preconcentration, our data on tdCo and dCo are highly reproducible. It has been proposed that UV irradiation prior to preconcentration is necessary to determine the total dCo (Biller and Bruland, 2012; Milne et al., 2010; Saito and Moffett, 2001). Actually, it appears that our dCo concentrations were significantly lower than those for samples collected near the Hawaii Islands, which were subjected to UV irradiation (Supplementary Fig. 11a) (Noble et al., 2008). We applied UV irradiation to a mixed sample of North Pacific surface water and found an increase in dCo concentration by $\sim 20 \%$. The analytical data for the reference seawater samples also show similar results (Supplementary Table 2). Thus, it should be noted that our Co data are operational and may be lower than those with UV irradiation. Some studies reported that the difference between UV irradiated and non-UV irradiated values varies throughout a water column (Noble et al., 2017; Shelley et al., 2010). However, both the tdCo and dCo are reproducible and show systematic trends as described below. The difference caused by UV irradiation will not qualitatively affect the major points of our discussion, such as those on the basis of the enrichment factor (section 4.4) and the Co/Mn ratio (section 4.5). In addition, the non-labile Co that can be detected after UV irradiation has not been identified yet. It is probable that future comparison between Co data with and without UV will contribute to the characterization of non-labile Co. Therefore, we think our Co data will be informative for the community of chemical oceanography research.

Third, it appears that no significant change occurred in the subsurface $\mathrm{Pb}$ maximum from 1977 to the present time in the North Pacific. As an example, the vertical profiles of $\operatorname{tdPb}$ in $20^{\circ} \mathrm{N}-35^{\circ} \mathrm{N}, 145^{\circ} \mathrm{W}-160^{\circ} \mathrm{W}$ from 1976 to 2005 are compared in Supplementary Fig. 11b. Because the tdPb concentration depends on the location, it is not easy to extract the temporal change from these data. However, we can say the subsurface $\mathrm{tdPb}$ maximum has been maintained at $63-82 \mathrm{pmol} \mathrm{kg}^{-1}$ for 30 years in this area. This is an important characteristic in the North Pacific Ocean. In contrast, a substantial decrease in the subsurface $\mathrm{Pb}$ maximum has been observed in the North Atlantic. A decrease of $\sim 150 \mathrm{pmol} \mathrm{kg}^{-1}$ during 1979-2011 was found near Bermuda, which is attributed to the phase-out of leaded gasoline in the United States and in Europe (Lee et al., 2011). The decline in the Pb concentration in 

the Atlantic has also been found along the transect GEOTRACES GA-01 (Zurbrick et al., 2018). In the North Pacific, it has been reported that the decreasing supply from gasoline has been canceled out by the growing supply from coal combustion, metal smelting, and municipal solid waste incineration mainly from China, Russia, and Japan (Zurbrick et al., 2017). The same trend has been shown for ice core data (Gross et al., 2012).

Finally, our data suggest that crossover stations near the continental shelves, such as TR16 and BD07, are not ideal for intercomparison of scavenged trace metals. These metals are affected by temporal and spatial variations in the ocean boundary environment. Therefore, for unambiguous intercomparison, a crossover station should be located far from the continental shelves and the offshore side of the boundary scavenging zone.

\subsection{Labile particulate and dissolved fractions}

The lpM concentration is operationally defined as the difference in concentrations between tdM and dM. Data of particulate concentrations are scarce in the North Pacific. In this study, we compared our dM and lpM data from ST09 $\left(30.007^{\circ} \mathrm{N}, 159.996^{\circ} \mathrm{W}\right)$ with the $\mathrm{dM}$ and particulate $\mathrm{M}(\mathrm{pM})$ data from the Vertex IV site $\left(28^{\circ} \mathrm{N}, 155^{\circ} \mathrm{W}\right)$ (Bruland et al., 1994). The authors collected particulate samples on a Nuclepore filter with a pore size of $0.3 \mu \mathrm{m}$, and analyzed them for the trace metal content of both the $25 \%$ acetic acid leachate and the residual refractory fraction that was treated with $\mathrm{HCl}-\mathrm{HNO}_{3}-\mathrm{HF}$. Figure $8 \mathrm{~b}$ shows the results of pAl, which were mostly in the refractory fraction. Our lpAl concentration at ST09 was similar to or higher than the total pAl concentration at Vertex IV. Because ST09 is located about $800 \mathrm{~km}$ from the Hawaiian Seamount Chain, it is possible that the total pAl concentration is elevated compared with Vertex IV. This is consistent with the dAl concentration at depths of 2000-3000 $\mathrm{m}$ is higher at ST09 than that at Vertex IV (Fig. 8a). Thus, we can expect that lpAl represents a major fraction of total pAl. Supplementary Fig. 12 shows the results for $\mathrm{dMn}$ and $\mathrm{pMn}$. Although some of the lpMn concentration at ST09 was less than the detection limit, the general trend was similar between lpMn at ST09 and total pMn at Vertex IV, suggesting that lpMn is a good measure of total pMn. The same results were also observed for Fe, which is reported in the forthcoming paper. No data from the 
552 literature are available for comparison of $\mathrm{pCo}$ and $\mathrm{pPb}$ in this area. Around the Juan de Fuca

553 Ridge, we found that the $1 \mathrm{pFe} / \mathrm{lpAl}, \mathrm{lpMn} / \mathrm{lpAl}, \mathrm{lpCo} / \mathrm{lpAl}$, and $\mathrm{lpPb} / \mathrm{lpAl}$ ratios in the bottom 554 water are close to the ratios of total concentrations in the bottom sediments (Zheng et al., 555 2017). On the basis of these results, we suggest that $1 \mathrm{pM}$ represents a major fraction of total 556 pM. We think lpM includes metals desorbed or released from aluminosilicates, metal oxides, 557 and the degradation of phytoplankton and bacteria.

558 Supplementary Fig. 13 shows histograms of the $1 \mathrm{pM} / \mathrm{tdM}$ ratio for each metal in the 559 North Pacific Ocean. It is apparent that the four metals are classified in the scavenged group 560 but have very different speciations among $\mathrm{d}$ and $\mathrm{p}$ species. The $\mathrm{lpAl} / \mathrm{tdAl}$ ratio is $0.66 \pm 0.31$ 561 (average $\pm \mathrm{sd}, n=489)$, the $\mathrm{lpMn} / \mathrm{tdMn}$ ratio is $0.24 \pm 0.24(n=628)$, the $1 \mathrm{pCo} / \mathrm{tdCo}$ ratio is $5620.12 \pm 0.18(n=620)$, and the $\mathrm{lpPb} / \mathrm{tdPb}$ ratio is $0.02 \pm 0.08(n=575)$. Because $\mathrm{Al}$ is the 563 major element in the upper crust, a large amount of $1 \mathrm{pAl}$ is supplied from the lithosphere to 564 the ocean. Another major factor controlling the lpM/tdM ratio should be adsorption in the 565 ocean. The adsorption is explained by the surface complexation model (Li, 1981). Inorganic 566 minerals such as aluminosilicates and iron hydroxides have surface hydroxide groups that 567 form surface complexes with metal ions. The stability of the surface complex has a linear relationship with the first hydrolysis constant for the metal ion. Because Al forms a trivalent cation in seawater, it has the highest hydrolysis constant, resulting in the highest $\mathrm{lpM} / \mathrm{tdM}$ ratio. Although the hydrolysis constant of $\mathrm{Pb}(\mathrm{II})$ is higher than that of $\mathrm{Mn}(\mathrm{II})$ and $\mathrm{Co}(\mathrm{II})$ ( $\mathrm{Li}$, 1981), Mn(II) is most readily oxidized to Mn(III) or Mn(IV) (Mandernack et al., 1995; 572 Moffett and Ho, 1996), resulting in a higher lpM/tdM ratio. Moreover, it is likely that $\operatorname{Co}(\mathrm{II})$ 573 is more readily oxidized to $\mathrm{Co}$ (III) than $\mathrm{Pb}$ (II) is oxidized to $\mathrm{Pb}$ (IV), because $\mathrm{Co}$ (II) is 574 co-oxidized with $\mathrm{Mn}(\mathrm{II})$ via a common microbially catalyzed pathway (Moffett and Ho, 575 1996).

The vertical distributions of the $1 \mathrm{pM} / \mathrm{tdM}$ ratio are also distinct among the scavenged elements (Fig. 9). The lpAl/tdAl ratio is uniformly high at high latitudes. The ratio 578 is lower at low latitudes, especially in surface water, probably due to supply of dAl via 579 surface and subsurface currents from lands in the tropical zone where intense weathering 580 occurs. The lpMn/tdMn ratio shows a generally increasing trend with depth, without a 
581 significant change with the latitude. This probably reflects the effects of oxidative scavenging

582 throughout the water column. The $\mathrm{lpCo} / \mathrm{tdCo}$ ratio shows a trend that is generally increasing 583 in deep water, similar to the $\mathrm{lpMn} / \mathrm{tdMn}$ ratio, while the former is significantly lower than the 584 latter. In addition, high values of the $\mathrm{lpCo} / \mathrm{tdCo}$ ratio occur in surface water at lower latitudes 585 due to the uptake of dCo by phytoplankton.

\subsection{Lithogenic effects presented by $\mathrm{Al}$}

Our data show that tdAl is a good tracer of LCDW in the North Pacific (Fig. 2e, Supplementary Figs. 1e and 2e, and Fig. 4a). In Fig. 10, the tdAl concentration is plotted on the temperature-salinity diagram. The graph indicates that waters with $\sigma_{\theta}>27.8$ are enriched with tdAl. In particular, tdAl is useful because tracking LCDW in the northern North Pacific is not easy when using conventional oceanographic parameters. Total dissolvable Al is not only supplied by the LCDW from the South Pacific but also added locally by resuspension of sediments in the North Pacific. The relative contributions from transport via LCDW and from resuspension are unclear at present and would be a challenge in future study. In contrast, dAl

596 decreases when the LCDW flows from south to north in the North Pacific (Fig. 4b). 597 Supplementary Fig. 14 shows that the dAl concentration decreases with latitude at depths greater than $4500 \mathrm{~m}$, where the LCDW flows. The LCDW is the only origin of deep water dAl in the North Pacific; no other water supplies dAl to the depths. When the LCDW flows in the North Pacific, dAl is gradually adsorbed onto particles. In addition, lpAl is added to the

601 LCDW by resuspension of bottom sediments during the track, although the supply of dAl 602 from the bottom sediments is negligible. Overall, the dAl concentration in deep waters 603 decreases from about $4 \mathrm{nmol} \mathrm{kg}^{-1}$ around the equator to about $1 \mathrm{nmol} \mathrm{kg}^{-1}$ around $50^{\circ} \mathrm{N}$. It 604 takes about 100 years for the LCDW to travel from the equator to $50^{\circ} \mathrm{N}$ (Matsumoto, 2007); 605 the apparent decreasing rate of $\mathrm{dAl}$ is $0.03 \mathrm{nmol} \mathrm{kg}^{-1} \mathrm{y}^{-1}$ in deep waters in the North Pacific 606 Ocean. 
610

611

612

613

614

615

616

enrichment factor $(E F)$ of $\mathrm{dM}$ in seawater over the upper crust is defined in accordance with the $E F$ of $\mathrm{M}$ in aerosols in the literature (Rahn, 1976) as follows:

$$
E F(\mathrm{dM})=(\mathrm{dM} / \mathrm{dAl})_{\text {seawater }} /(\mathrm{M} / \mathrm{Al})_{\text {upper crust }}
$$

The $(\mathrm{M} / \mathrm{Al})_{\text {upper crust }}$ is calculated in moles using concentrations published in a review (Rudnick and Gao, 2005) as the following: $4.7 \times 10^{-3}$ for Mn, $9.7 \times 10^{-5}$ for $\mathrm{Co}$, and $2.7 \times$ $10^{-5}$ for $\mathrm{Pb}$. Figure 11 shows box plots of $E F(\mathrm{dM})$. The median is $1.3 \times 10^{2}(n=436)$ for $E F(\mathrm{dMn}), 3.2 \times 10^{2}(n=430)$ for $E F(\mathrm{dCo})$, and $1.2 \times 10^{3}(n=413)$ for $E F(\mathrm{dPb})$. The median of $E F(\mathrm{dPb})$ is on the same order as that of $E F$ for aerosols in the literature (Rahn, 1976), suggesting that aerosols are a major source of $\mathrm{dPb}$. For $\mathrm{Mn}$ and $\mathrm{Co}$, the $E F$ for aerosols is usually 1-10. Thus, $E F(\mathrm{dMn})$ and $E F(\mathrm{dCo})$ are ten to hundred times higher than the $E F$ for aerosols. This would be partly due to the differences in solubility of the metals in aerosols. As an example, Baker et al. (2006) reported that the solubility of Mn is several to ten times higher than that of Al. Another important cause would be that sources other than aerosols are more significant contributors to $\mathrm{Mn}$ and Co. Sectional distributions of $E F(\mathrm{dM})$ and $E F(\mathrm{lpM})$ along $160^{\circ} \mathrm{W}$ and $47^{\circ} \mathrm{N}$ are given in Supplementary Figs. 15 and 16, respectively. These figures show that the other sources of $\mathrm{dMn}$ and $\mathrm{dCo}$ are restricted to shallow depths near the northern boundaries of the North Pacific.

Figure 2 shows the sectional distributions of $\mathrm{dM}$ and $\mathrm{lpM}$ in the upper ocean along $160^{\circ} \mathrm{W}$. It is clear that each element has different sources and is uniquely related to the ocean circulation. The dAl concentration is high in the EUC and NEC. The transport of Al by the EUC from New Guinea and New Ireland has been reported in the literature (Kaupp et al., 2011; Slemons et al., 2012). The source of dAl in the NEC should be the Hawaiian Islands. The elevated $\mathrm{dAl}$ concertation near the Hawaiian Islands has been reported in the literature (Measures et al., 2005). In contrast, the $\mathrm{dAl}$ concentration is low in northern currents, such as the AS. Similarly, high dAl concentrations in tropical currents have been found in the Indian Ocean (Vu and Sohrin, 2013). These results are ascribed to supply of dAl via surface and subsurface currents from lands in the tropical zone where intense weathering occurs. The dMn concentration is high in the AS, suggesting the source is manganese reduction in sediments on the continental shelf. Substantially high dMn concentrations have been observed over the 
639 Bering Sea shelf (Cid et al., 2011). A surface maximum of dMn occurs between $7^{\circ} \mathrm{N}$ and $64026^{\circ} \mathrm{N}$, suggesting the effect of photoreduction (Sunda and Huntsman, 1988). The dCo 641 concentration is high in the AS, suggesting the same reductive source with $\mathrm{dMn}$. These results 642 are also consistent with the observation in the Bering Sea (Cid et al., 2011). A remarkable 643 feature of dCo is that it expands through the NPIW and EqPIW over the North Pacific. The 644 subsurface maximum of $\mathrm{dPb}$ occurs between $20^{\circ} \mathrm{N}$ and $45^{\circ} \mathrm{N}$, corresponding with the STMW 645 and CMW in the subtropical gyre. Supplementary Figs. 5 and 6 shows the sectional 646 distributions of $\mathrm{dM}$ in the upper ocean along $165^{\circ} \mathrm{E}$ and $47^{\circ} \mathrm{N}$, respectively. These 647 distributions also indicate that $\mathrm{dMn}$ and $\mathrm{dCo}$ are derived from the same sources on the 648 continental shelves, which do not contribute significantly to $\mathrm{dPb}$.

Figure 5 shows distinct horizontal distributions of tdCo and $\mathrm{tdPb}$ over the North 650 Pacific. For tdCo, the concentration on an isopycnal plane of $26.8 \sigma_{\theta}$ is presented. It is clear 651 that tdCo originated from the northern shelves and spread southward. For tdPb, the highest 652 subsurface concentration maximum is presented because the $\sigma_{\theta}$ value for the $\mathrm{tdPb}$ maximum significantly increases from west to east. The highest tdPb occurs in the subtropical gyre and decreases from west to east. This horizontal distribution of $t \mathrm{dPb}$ is consistent with that of radioactive ${ }^{210} \mathrm{~Pb}$ in the surface water (Nozaki et al., 1976).

\subsection{Redox and biogeochemical control on Co}

As discussed above, Co and Mn have a common source in the continental shelf sediments. In hydrothermal plumes around the Juan de Fuca Ridge, the concentration of Mn 660 increases remarkably and that of Co does not. This is because the flux of Mn from 661 hydrothermal vents is considerably higher than that of Co (Seyfried Jr et al., 2003). In 662 addition, the solubility product is much lower for $\operatorname{CoS}$ than MnS (Chemical et al., 1964), 663 although the solubility of Co increases with increasing chloride concentration (Seyfried Jr et 664 al., 2003). Thus, Co is not transported far by hydrothermal plumes. Supplementary Fig. 17a 665 shows the relationship between $\mathrm{dCo}$ and $\mathrm{dMn}$ in water columns above the depth of 666 hydrothermal plumes $\left(\sigma_{\theta}<27.64\right)$. The following overall linear relationship is present: 
668 This slope is nearly consistent with the ratio of $\mathrm{Co} / \mathrm{Mn}=2.1 \times 10^{-2}$ for average mole 669 concentrations in the upper crust (Rudnick and Gao, 2005). These results imply that the 670 ultimate source of $\mathrm{Mn}$ and Co in the North Pacific Ocean has a Co/Mn ratio similar to that in the upper crust. However, most data in the graph are along another line with a higher slope, which means that $\mathrm{dCo}$ and $\mathrm{dMn}$ are substantially fractionated in the North Pacific. Pacific. Although both $\mathrm{Mn}$ and Co are taken up by phytoplankton as micronutrients, the concentration factor of Co in phytoplankton is much higher than that of Mn (Morel et al., 2003). As a result, the effects of biogeochemical cycles are apparent only in the distribution of Co in the ocean. The dCo concentration is low in the surface water except at stations near continental shelves (Fig. 3c and Supplementary Figs. 5b and 6c). This is ascribed to the uptake of Co by phytoplankton. Supplementary Fig. 17b shows the general relationship of dCo against phosphate in water columns above the depth of the NPIW $\left(\sigma_{\theta}<26.5\right)$ :

$$
\mathrm{dCo}\left(\mathrm{pmol} \mathrm{kg}{ }^{-1}\right)=36.4 \mathrm{PO}_{4}\left(\mu \mathrm{mol} \mathrm{kg}{ }^{-1}\right)+6.4 \quad(r=0.692, p<0.0001, n=176)
$$

These results are mostly consistent with the data on total dCo in the literature (Hawco et al., 2018; Noble et al., 2008; Saito et al., 2017), which suggest that dCo is taken up by phytoplankton and is remineralized from settled particles concurrently with phosphate. The $\mathrm{dCo} /$ phosphate ratio tends to be higher at higher latitudes. Particularly high ratios were found in the surface water at ST14 in the AS. Biogeochemical effects are also apparent in the vertical distribution of the $\mathrm{dCo} / \mathrm{dMn}$ ratio (Fig. 12). The ratio becomes lower in surface water according to the selective uptake and removal of dCo by phytoplankton and increases with depth above the NPIW with $\sigma_{\theta}=26.8$, through remineralization. Another cause for the high $\mathrm{dCo} / \mathrm{dMn}$ ratio in waters with $\sigma_{\theta}>26$ should be the microbial oxidation of $\mathrm{dMn}$, which is

691 7-10 times faster than that of dCo (Moffett and Ho, 1996), resulting in the selective 692 transformation from dMn to lpMn. Below the NPIW, no clear relationship is apparent between the $\mathrm{dCo}$ and phosphate, and the $\mathrm{dCo} / \mathrm{dMn}$ ratio decreases. Because the concentrations

694 of $\mathrm{O}_{2}$ and biogenic particulate organic matter decrease below the NPIW, scavenging becomes predominant over remineralization for the distribution of $\mathrm{dCo}$. 


\subsection{Anthropogenic control on $\mathrm{Pb}$}

In this paper, we report the basin-scale distribution of stable $\mathrm{Pb}$ in the North Pacific for the first time. The subsurface maximum centered at $\sim 26 \sigma_{\theta}$ is a basin-scale characteristic. The maximum concentration tends to decrease from west to east. In addition, $E F(\mathrm{dPb})$ is as high as $E F$ for aerosols. These results further support the anthropogenic control on $\mathrm{Pb}$ in the North Pacific, which has been discussed in previous research (Boyle et al., 2005; Zurbrick et al., 2017). To summarize, anthropogenic $\mathrm{Pb}$ originating from China, Japan, and Russia is carried to the North Pacific as aerosols by westerlies centered at $\sim 35^{\circ} \mathrm{N}$, deposited on the sea surface, and dissolved in the mixed layer during formation of the STMW and CMW. Although $\mathrm{dPb}$ is quickly scavenged from the surface water by biogenic particles, it has a longer residence time in subsurface water and spreads over the North Pacific by current systems of subtropical and subarctic gyres. This mechanism is not as important for Al, Mn, and Co because these metals are less enriched in industrial aerosols. For example, the enrichment factor of $\mathrm{Pb}$ was $10-100$ times higher than that of $\mathrm{Mn}$ and $\mathrm{Co}$ in atmospheric deposition samples collected around Japan (Okubo et al., 2013).

In deep water $\left(\sigma_{\theta}>26.7\right)$, a linear relationship between $\mathrm{dPb}$ and $\mathrm{dCo}$ is observed (Fig. 13):

$$
\mathrm{dPb}\left(\mathrm{pmol} \mathrm{kg}^{-1}\right)=1.06 \mathrm{dCo}\left(\mathrm{pmol} \mathrm{kg}^{-1}\right)-3.1 \quad(r=0.868, p<0.0001, n=374)
$$

which suggests the concurrent effect of scavenging. Because there are no significant sources for both metals in deep waters, a common property emerges for the scavenged elements. The $\mathrm{dPb} / \mathrm{dCo}$ ratio tends to be higher at higher latitudes. This probably reflects the dependency of atmospheric aerosol deposition flux on the latitude. In shallow waters, no significant relationship is observed between $\mathrm{dPb}$ and $\mathrm{dCo}$, which reflects different sources for these metals. Clearly, anthropogenic $\mathrm{Pb}$ sources contribute to high concentrations mostly in warm surface waters of the temperate zone (Fig. 3d and Supplementary Fig. 5c).

Interestingly, radiocesium emitted from the Fukushima Daiichi Nuclear Power Plant $\left(37^{\circ} 25^{\prime} \mathrm{N}, 141^{\circ} 02^{\prime} \mathrm{E}\right)$ in March 2011 presently shows a distribution similar to that of $\mathrm{Pb}$ in the North Pacific (Aoyama et al., 2018; Kumamoto et al., 2014; Smith et al., 2017). As an example, Kumamoto et al. (2014) measured d radiocesium at stations along $149^{\circ} \mathrm{E}$ in winter 
2012 (Supplementary Fig. 18). In particular, they found a subsurface radiocesium maximum at a depth of $\sim 300 \mathrm{~m}$ around $32^{\circ} \mathrm{N}$, which is a characteristic similar to the subsurface maximum of $\mathrm{Pb}$. They concluded that atmosphere-deposited radiocesium south of the KE had been transported not only eastward along with surface currents but also southward owing to the formation/subduction of the STMW within about 10 months after the accident. Smith et al. (2017) reported that the Fukushima-derived radiocesium plume was first observed in June 2012 at the westernmost station on Line P, which is an oceanographic sampling line extending $1500 \mathrm{~km}$ westward of British Columbia, Canada. The plume spread over the Canadian continental shelf during 2013 and 2014. It is likely that anthropogenic contaminants in aerosols are entrained in the same distribution mechanism as that for $\mathrm{Pb}$. Although $\mathrm{Cs}$ is a conservative element in oceanography, the Fukushima-derived radiocesium followed $\mathrm{Pb}$ in the manner of its distribution mechanism and spread over the North Pacific, at least during the first several years after the accident.

\section{CONCLUSIONS}

We observed basin-scale and full-depth sectional distributions of $\mathrm{Al}, \mathrm{Mn}, \mathrm{Co}$, and $\mathrm{Pb}$ in the North Pacific using a multi-elemental determination method and without using UV irradiation. This study revealed that the speciation of the $\mathrm{dM}$ and $\mathrm{pM}$ fractions differs significantly among the four metals. Analysis based on stoichiometry revealed that $\mathrm{Mn}, \mathrm{Co}$, and $\mathrm{Pb}$ are dominated by different sources than those of $\mathrm{Al}$ and that each element is a unique tracer for distinct currents and water masses. However, despite the apparent differences, these elements should be grouped as scavenged elements. The four metals are affected by scavenging throughout the ocean, although the relative intensity of the other processes controls the distribution of each metal. As an example, $\mathrm{Co}$ and $\mathrm{Pb}$ show a strong correlation in the deep waters of the North Pacific, where no significant sources occur for these metals, and scavenging is the predominant process. In contrast, the differences between Co and $\mathrm{Mn}$ in terms of the oxidation rate, the enrichment by phytoplankton, and the effect of hydrothermal plumes cause substantial fractionations of $\mathrm{dCo}$ and $\mathrm{dMn}$ in the North Pacific. 
We propose $E F(\mathrm{dM})$ as a potential parameter to systematically explain inter-basin

756 variations in the distribution of $\mathrm{dM}$. Dissolved $\mathrm{Al}$ occurs in a wider concentration range in the

757 world's oceans than the other metals. Because dAl concentration is normally low in the North 758 Pacific, $E F$ is high for $\mathrm{dMn}, \mathrm{dCo}$, and $\mathrm{dPb}$, resulting in the unique distribution of each metal.

759 Since dAl concentration is substantially higher in the Atlantic Ocean and the Mediterranean 760 Sea, features common with dAl may emerge for $\mathrm{dMn}, \mathrm{dCo}$, and $\mathrm{dPb}$.

\section{ACKNOWLEDGEMENTS}

This research was supported by The Japan Society for the Promotion of Science (JSPS) KAKENHI grants (Grant Nos. JP16204046, JP21350042, JP24241004, and JP15H0127), by grants from the Steel Foundation for Environmental Protection Technology, and by Mitsumasa Ito Memorial Research Grant from the Research Institute for

768 Oceanochemistry Foundation. The authors thank the crew, technicians, students, and scientists onboard the KH-05-2, KH-11-7, and KH-12-4 cruises for assistance with sampling and analysis of routine data. We would like to thank Editage (www.editage.jp) for English

771 language editing. Finally, we thank three anonymous reviewers and the associate editor Tina van de Flierdt for their helpful and constructive comments. 
776

777

778

779

780

781

782

783

784

785

786

787

Figure Captions

Fig. 1. A map showing the locations of the data collected in this study. The white lines show surface currents and the dashed line shows the subsurface current.

Fig. 2. Full-depth sectional distribution of salinity, $\mathrm{O}_{2}$, silicate, phosphate, and $\operatorname{tdM}$ along $160^{\circ}$ W. EqPIW: Equatorial Pacific Intermediate Water; NPIW: North Pacific Intermediate Water; UCDW: Upper Circumpolar Deep Water; LCDW: Lower Circumpolar Deep Water; PDW: Pacific Deep Water; AS: Alaskan Stream; STMW: Subtropical Mode Water.

Fig. 3. Sectional distributions of $\mathrm{dM}$ and $\mathrm{lpM}$ at depths of $0-1000 \mathrm{~m}$ along $160^{\circ} \mathrm{W}$. EUC: Equatorial Under Current; NEC: North Equatorial Current; AS: Alaskan Stream; EqPIW: Equatorial Pacific Intermediate Water; NPIW: North Pacific Intermediate Water; STMW: Subtropical Mode Water; CMW: Central Mode Water.

Fig. 4. The distributions of tdAl and dAl at a depth of $4500 \mathrm{~m}$. The red line shows the major flows of the LCDW, which were taken from the literature (Kawabe and Fujio, 2010). A number in a circle shows the volume transport of the current in $\mathrm{Sv}\left(10^{6} \mathrm{~m}^{3} \mathrm{~s}^{-1}\right)$. The number $4^{+}\left(4^{-}\right)$means a little more (less) than $4 \mathrm{~Sv}$. A circle with a center point shows upwelling from this layer; its transport volume is shown by an accompanying number.

Fig. 5. (a) The horizontal distribution of tdCo on the isopycnal plane of $26.8 \sigma_{\theta}$. (b) The horizontal distribution of the maximum $\mathrm{tdPb}$ in the water column, which occurs in the subsurface water.

Fig. 6. Vertical profiles of tdM at ST13 (red circles), BD15 (blue squares), and ST14 (cyan diamonds).

Fig. 7. (a) and (b): The vertical profiles of tdAl and dAl at TR16 (red circles) and BD07 (blue squares). The distribution of earthquakes (magnitude > 5) around the Kuril-Kamchatka 
805 Trench from February 28 to July 28, 2011 (c), and from March 28 to August 28, 2012 (d). A

806 black circle represents a seismic center and the diameter of such a circle represents the 807 relative magnitudes of the earthquakes. The data were taken from https://earthquake.usgs.gov.

808

809

810

811

812

813

814

815

816

817

818

819

820

821

822

823

824

825

826

827

828

829

830

831

832

Fig. 8. Vertical profiles of $\mathrm{dAl}$ and particulate $\mathrm{Al}(\mathrm{pAl})$. Red triangles represent $\mathrm{dAl}$ and $\mathrm{lpAl}$ at ST09 $\left(30.007^{\circ} \mathrm{N}, 159.996^{\circ} \mathrm{W}\right)$. Black marks represent data at the Vertex IV site $\left(28^{\circ} \mathrm{N}\right.$, $155^{\circ} \mathrm{W}$ ) (Bruland et al., 1994). (b) Open circles, squares, and diamonds represent acetic acid leachable pAl, refractory $\mathrm{pAl}$, and total pAl, respectively.

Fig. 9. Vertical distribution of the $1 \mathrm{pM} / \mathrm{tdM}$ ratio in the North Pacific. The colors of the dots represent the latitudes.

Fig. 10. Potential temperature-salinity diagram. The colors of the dots represent the tdAl concentrations.

Fig. 11. Box plots of $E F(\mathrm{dM})$ for $\mathrm{Mn}, \mathrm{Co}$, and $\mathrm{Pb}$. The middle line of the box represents the median; the top and bottom lines of the box represent the upper and lower quartiles, respectively; and circles represent potential outliers.

Fig. 12. The tdCo/tdMn ratio against the potential density anomaly in the North Pacific. The colors of the dots represent the latitudes. The black line shows the average $\mathrm{Co} / \mathrm{Mn}$ mole ratio of $2.1 \times 10^{-2}$ in the upper crust (Rudnick and Gao, 2005).

Fig. 13. The relationship between $\mathrm{dPb}$ and $\mathrm{dCo}$ in deep waters $\left(\sigma_{\theta}>26.7\right)$. The red line represents the regression line, the equation for which is presented in the text. The colors of the dots represent the latitudes. 


\section{3}

834

835

836

837

838

839

840

841

842

843

844

845

846

847

848

849

850

851

852

853

854

855

856

857

858

859

860

861

862

863

864

865

867

869

870 866 central North Pacific. Geochim. Cosmochim. Acta 58, 3171-3182. 868 C.M. (2005) Manganese and iron distributions off central California influenced by upwelling

\section{REFERENCES}

Aoyama, M., Hamajima, Y., Inomata, Y., Kumamoto, Y., Oka, E., Tsubono, T. and Tsumune, D. (2018) Radiocaesium derived from the TEPCO Fukushima accident in the North Pacific Ocean: Surface transport processes until 2017. J. Environ. Radioact. 189, 93-102.

Arai, K., et al. (2013) Tsunami-generated turbidity current of the 2011 Tohoku-Oki earthquake. Geology 41, 1195-1198.

Baker, A.R., Jickells, T.D., Witt, M. and Linge, K.L. (2006) Trends in the solubility of iron, aluminium, manganese and phosphorus in aerosol collected over the Atlantic Ocean. Mar. Chem. 98, 43-58.

Barrett, P.M., Resing, J.A., Buck, N.J., Landing, W.M., Morton, P.L. and Shelley, R.U. (2015) Changes in the distribution of $\mathrm{Al}$ and particulate Fe along $\mathrm{A} 16 \mathrm{~N}$ in the eastern North Atlantic Ocean between 2003 and 2013: Implications for changes in dust deposition. Mar. Chem. 177, Part 1, 57-68.

Biller, D.V. and Bruland, K.W. (2012) Analysis of Mn, Fe, Co, Ni, Cu, Zn, Cd, and Pb in seawater using the Nobias-chelate PA1 resin and magnetic sector inductively coupled plasma mass spectrometry (ICP-MS). Mar. Chem. 130-131, 12-20.

Biller, D.V. and Bruland, K.W. (2013) Sources and distributions of Mn, Fe, Co, Ni, Cu, Zn, and $\mathrm{Cd}$ relative to macronutrients along the central California coast during the spring and summer upwelling season. Mar. Chem. 155, 50-70.

Bostock, H.C., Opdyke, B.N. and Williams, M.J.M. (2010) Characterising the intermediate depth waters of the Pacific Ocean using d13C and other geochemical tracers. Deep-Sea Res. I 57, 847-859.

Boyle, E.A., Bergquist, B.A., Kayser, R.A. and Mahowald, N. (2005) Iron, manganese, and lead at Hawaii Ocean Time-series station ALOHA: Temporal variability and an intermediate water hydrothermal plume. Geochim. Cosmochim. Acta 69, 933-952.

Bridgestock, L., Rehkämper, M., van de Flierdt, T., Paul, M., Milne, A., Lohan, M.C. and Achterberg, E.P. (2018) The distribution of lead concentrations and isotope compositions in the eastern Tropical Atlantic Ocean. Geochim. Cosmochim. Acta 225, 36-51.

Bridgestock, L., et al. (2016) Return of naturally sourced $\mathrm{Pb}$ to Atlantic surface waters. Nat. Commun. 7, 12921.

Bruland, K.W. and Lohan, M.C. (2003) Controls of Trace Metals in Seawater, in: Elderfield, H. (Ed.), The Oceans and Marine Geochemistry. Elsevier-Pergamon, Oxford, pp. 23-47.

85 Bruland, K.W., Orians, K.J. and Cowen, J.P. (1994) Reactive trace metals in the stratified

867 Chase, Z., Johnson, K.S., Elrod, V.A., Plant, J.N., Fitzwater, S.E., Pickell, L. and Sakamoto, and shelf width. Mar. Chem. 95, 235-254.

Chemical, S., Sillén, L.G. and Martell, A.E. (1964) Stability constants of metal-ion complexes. 
871

872

873

874

875

876

877

878

879

880

881

882

883

884

885

886

887

888

889

890

891

892

893

894

895

896

897

898

899

900

901

902

903

904

905

906

907

908

909

Chemical Society.

Chester, R. (2000) Marine Geochemistry, 2nd ed. Blackwell, Malden.

Chien, C.-T., Ho, T.-Y., Sanborn, M.E., Yin, Q.-Z. and Paytan, A. (2017) Lead concentrations and isotopic compositions in the Western Philippine Sea. Mar. Chem. 189, 10-16.

Cid, A.P., Urushihara, S., Minami, T., Norisuye, K. and Sohrin, Y. (2011) Stoichiometry among bioactive trace metals in seawater on the Bering Sea shelf. J. Oceanogr. 67, 747-764.

Coale, K.H., Chin, C.S., Massoth, G.J., Johnson, K.S. and Baker, E.T. (1991) In situ chemical mapping of dissolved iron and manganese in hydrothermal plumes. Nature 352, 325-328.

Cowen, J.P., Massoth, G.J. and Feely, R.A. (1990) Scavenging rates of dissolved manganese in a hydrothermal vent plume. Deep-Sea Res. A 37, 1619-1637.

Echegoyen, Y., Boyle, E.A., Lee, J.-M., Gamo, T., Obata, H. and Norisuye, K. (2014) Recent distribution of lead in the Indian Ocean reflects the impact of regional emissions. Proc. Natl. Acad. Sci. USA 111, 15328-15331.

Ezoe, M., Ishita, T., Kinugasa, M., Lai, X., Norisuye, K. and Sohrin, Y. (2004) Distributions of dissolved and acid-dissolvable bioactive trace metals in the North Pacific Ocean. Geochem. J. 38, 535-550.

Flegal, A.R. and Patterson, C.C. (1983) Vertical concentration profiles of lead in the Central Pacific at $15^{\circ} \mathrm{N}$ and $20^{\circ} \mathrm{S}$. Earth Planet. Sci. Lett. 64, 19-32.

Flegal, A.R., Schaule, B.K. and Patterson, C.C. (1984) Stable isotopic ratios of lead in surface waters of the Central Pacific. Mar. Chem. 14, 281-287.

Froelich, P.N., et al. (1979) Early oxidation of organic matter in pelagic sediments of the eastern equatorial Atlantic: suboxic diagenesis. Geochim. Cosmochim. Acta 43, 1075-1090.

Fujishima, Y., Ueda, K., Maruo, M., Nakayama, E., Tokutome, C., Hasegawa, H., Matsui, M. and Sohrin, Y. (2001) Distribution of Trace Bioelements in the Subarctic North Pacific Ocean and the Bering Sea (the R/V Hakuho Maru Cruise KH-97-2). J. Oceanogr. 57, 261-273.

Gallon, C., Ranville, M.A., Conaway, C.H., Landing, W.M., Buck, C.S., Morton, P.L. and Flegal, A.R. (2011) Asian Industrial Lead Inputs to the North Pacific Evidenced by Lead Concentrations and Isotopic Compositions in Surface Waters and Aerosols. Environ. Sci. Technol. 45, 9874-9882.

Gehlen, M., Beck, L., Calas, G., Flank, A.M., Van Bennekom, A.J. and Van Beusekom, J.E.E. (2002) Unraveling the atomic structure of biogenic silica: evidence of the structural association of $\mathrm{Al}$ and $\mathrm{Si}$ in diatom frustules. Geochim. Cosmochim. Acta 66, 1601-1609.

Gross, B.H., Kreutz, K.J., Osterberg, E.C., McConnell, J.R., Handley, M., Wake, C.P. and Yalcin, K. (2012) Constraining recent lead pollution sources in the North Pacific using ice core stable lead isotopes. J. Geophys. Res.: Atmospheres 117, D16307.

Hawco, N.J., Lam, P.J., Lee, J.-M., Ohnemus, D.C., Noble, A.E., Wyatt, N.J., Lohan, M.C. and Saito, M.A. (2018) Cobalt scavenging in the mesopelagic ocean and its influence on global mass balance: Synthesizing water column and sedimentary fluxes. Mar. Chem. 201, 

151-166.

911 Hydes, D.J. (1979) Aluminum in Seawater: Control by Inorganic Processes. Science 205, 912 1260-1262.

913 Jones, C.J. and Murray, J.W. (1985) The geochemistry of manganese in the northeast Pacific 914 Ocean off Washington. Limnol. Oceanogr. 30, 81-92.

915 Kaupp, L.J., Measures, C.I., Selph, K.E. and Mackenzie, F.T. (2011) The distribution of 916 dissolved Fe and $\mathrm{Al}$ in the upper waters of the Eastern Equatorial Pacific. Deep-Sea Res. II 58, 917 296-310.

918 Kawabe, M. and Fujio, S. (2010) Pacific ocean circulation based on observation. J. Oceanogr. $91966,389-403$.

920 Kawagucci, S., et al. (2012) Disturbance of deep-sea environments induced by the M9.0 921 Tohoku Earthquake. Sci. Rep. 2, 270.

922 Klinkhammer, G.P. (1980) Observations of the distribution of manganese over the East 923 Pacific Rise. Chem. Geol. 29, 211-226.

924 Klinkhammer, G.P. and Bender, M.L. (1980) The distribution of manganese in the Pacific 925 Ocean. Earth Planet. Sci. Lett. 46, 361-384.

926 Knap, A.H., Michaels, A., Close, A.R., Ducklow, H. and Dickson, A.G. (1996) Protocols for 927 the Joint Global Ocean Flux Study (JGOFS) Core Measurements.

928 Knauer, G.A., Martin, J.H. and Gordon, R.M. (1982) Cobalt in north-east Pacific waters. 929 Nature 297, 49-51.

930 Kramer, J., Laan, P., Sarthou, G., Timmermans, K.R. and de Baar, H.J.W. (2004) Distribution 931 of dissolved aluminium in the high atmospheric input region of the subtropical waters of the 932 North Atlantic Ocean. Mar. Chem. 88, 85-101.

933 Kumamoto, Y., Aoyama, M., Hamajima, Y., Aono, T., Kouketsu, S., Murata, A. and Kawano,

934 T. (2014) Southward spreading of the Fukushima-derived radiocesium across the Kuroshio 935 Extension in the North Pacific. Sci. Rep. 4, 4276.

936 Landing, W.M. and Bruland, K.W. (1980) Manganese in the North Pacific. Earth Planet. Sci. 937 Lett. 49, 45-56.

938 Lee, J.-M., Boyle, E.A., Echegoyen-Sanz, Y., Fitzsimmons, J.N., Zhang, R. and Kayser, R.A. 939 (2011) Analysis of trace metals $(\mathrm{Cu}, \mathrm{Cd}, \mathrm{Pb}$, and $\mathrm{Fe})$ in seawater using single batch 940 nitrilotriacetate resin extraction and isotope dilution inductively coupled plasma mass 941 spectrometry. Anal. Chim. Acta 686, 93-101.

942 Lee, J.-M., Boyle, E.A., Gamo, T., Obata, H., Norisuye, K. and Echegoyen, Y. (2015) Impact 943 of anthropogenic $\mathrm{Pb}$ and ocean circulation on the recent distribution of $\mathrm{Pb}$ isotopes in the 944 Indian Ocean. Geochim. Cosmochim. Acta 170, 126-144.

945 Li, Y.-H. (1981) Ultimate removal mechanisms of elements from the ocean. Geochim. 946 Cosmochim. Acta 45, 1659-1664.

947 Mackenzie, F.T., Stoffyn, M. and Wollast, R. (1978) Aluminum in Seawater: Control by 948 Biological Activity. Science 199, 680. 
949

950

951

952

953

954

955

956

957

958

959

960

961

962

963

964

965

966

967

968

969

970

971

972

973

974

975

976

977

978

979

980

981

982

983

984

985

986

987

Mandernack, K.W., Post, J. and Tebo, B.M. (1995) Manganese mineral formation by bacterial spores of the marine Bacillus, strain SG-1: Evidence for the direct oxidation of $\mathrm{Mn}$ (II) to Mn(IV). Geochim. Cosmochim. Acta 59, 4393-4408.

Maring, H.B. and Duce, R.A. (1987) The impact of atmospheric aerosols on trace metal chemistry in open ocean surface seawater, 1. Aluminum. Earth Planet. Sci. Lett. 84, 381-392.

Martin, J.H. and Knauer, G.A. (1980) Manganese cycling in northeast Pacific waters. Earth Planet. Sci. Lett. 51, 266-274.

Martin, J.H. and Knauer, G.A. (1984) VERTEX: manganese transport through oxygen minima. Earth Planet. Sci. Lett. 67, 35-47.

Martin, J.H., Knauer, G.A. and Broenkow, W.W. (1985) VERTEX: the lateral transport of manganese in the northeast Pacific. Deep-Sea Res. A 32, 1405-1427.

Matsumoto, K. (2007) Radiocarbon-based circulation age of the world oceans. J. Geophys. Res. 112, C09004.

Measures, C., Hatta, M., Fitzsimmons, J. and Morton, P. (2015) Dissolved Al in the zonal N Atlantic section of the US GEOTRACES 2010/2011 cruises and the importance of hydrothermal inputs. Deep-Sea Res. II 116, 176-186.

Measures, C.I., Brown, M.T. and Vink, S. (2005) Dust deposition to the surface waters of the western and central North Pacific inferred from surface water dissolved aluminum concentrations. Geochem. Geophys. Geosyst. 6, Q09M03.

Measures, C.I. and Vink, S. (2000) On the use of dissolved aluminum in surface waters to estimate dust deposition to the ocean. Global Biogeochem. Cycles 14, 317-327.

Middag, R., de Baar, H.J.W., Laan, P., Cai, P.H. and van Ooijen, J.C. (2011a) Dissolved manganese in the Atlantic sector of the Southern Ocean. Deep-Sea Res. II 58, 2661-2677.

Middag, R., van Hulten, M.M.P., Van Aken, H.M., Rijkenberg, M.J.A., Gerringa, L.J.A., Laan, P. and de Baar, H.J.W. (2015) Dissolved aluminium in the ocean conveyor of the West Atlantic Ocean: Effects of the biological cycle, scavenging, sediment resuspension and hydrography. Mar. Chem. 177, Part 1, 69-86.

Middag, R., van Slooten, C., de Baar, H.J.W. and Laan, P. (2011b) Dissolved aluminium in the Southern Ocean. Deep-Sea Res. II 58, 2647-2660.

Milne, A., Landing, W., Bizimis, M. and Morton, P. (2010) Determination of Mn, Fe, Co, Ni, $\mathrm{Cu}, \mathrm{Zn}, \mathrm{Cd}$ and $\mathrm{Pb}$ in seawater using high resolution magnetic sector inductively coupled mass spectrometry (HR-ICP-MS). Anal. Chim. Acta 665, 200-207.

Minakawa, M., Noriki, S. and Tsunogai, S. (1998) Manganese in the Bering Sea and the northern North Pacific Ocean. Geochem. J. 32, 315-329.

Minami, T., Konagaya, W., Zheng, L., Takano, S., Sasaki, M., Murata, R., Nakaguchi, Y. and Sohrin, Y. (2015) An off-line automated preconcentration system with ethylenediaminetriacetate chelating resin for the determination of trace metals in seawater by high-resolution inductively coupled plasma mass spectrometry. Anal. Chim. Acta 854, 183-190. 
988

989

990

991

992

993

994

995

996

997

998

999

1000

1001

1002

1003

1004

1005

1006

1007

1008

1009

1010

1011

1012

1013

1014

1015

1016

1017

1018

1019

1020

1021

1022

1023

1024

1025

1026

Moffett, J.W. and Ho, J. (1996) Oxidation of cobalt and manganese in seawater via a common microbially catalyzed pathway. Geochim. Cosmochim. Acta 60, 3415-3424.

Moran, S.B. and Moore, R.M. (1988) Evidence from mesocosm studies for biological removal of dissolved aluminium from sea water. Nature 335, 706-708.

Morel, F.M.M., Milligan, A.J. and Saito, M.A. (2003) Marine bioinorganic chemistry: the role of trace metals in the oceanic cycles of major nutrients, in: Elderfield, H. (Ed.), The Oceans and Marine Geochemistry. Elsevier-Pergamon, Oxford, pp. 113-143.

Nakatsuka, S., Okamura, K., Norisuye, K. and Sohrin, Y. (2007) Simultaneous determination of suspended particulate trace metals $(\mathrm{Co}, \mathrm{Ni}, \mathrm{Cu}, \mathrm{Zn}, \mathrm{Cd}$ and $\mathrm{Pb})$ in seawater with small volume filtration assisted by microwave digestion and flow injection inductively coupled plasma mass spectrometer. Anal. Chim. Acta 594, 52-60.

Noble, A.E., Echegoyen-Sanz, Y., Boyle, E.A., Ohnemus, D.C., Lam, P.J., Kayser, R., Reuer, M., Wu, J. and Smethie, W. (2015) Dynamic variability of dissolved $\mathrm{Pb}$ and $\mathrm{Pb}$ isotope composition from the U.S. North Atlantic GEOTRACES transect. Deep-Sea Res. II 116, 208-225.

Noble, A.E., et al. (2012) Basin-scale inputs of cobalt, iron, and manganese from the Benguela-Angola front to the South Atlantic Ocean. Limnol. Oceanogr. 57, 989-1010.

Noble, A.E., Ohnemus, D.C., Hawco, N.J., Lam, P.J. and Saito, M.A. (2017) Coastal sources, sinks and strong organic complexation of dissolved cobalt within the US North Atlantic GEOTRACES transect GA03. Biogeosciences 14, 2715-2739.

Noble, A.E., Saito, M.A., Maiti, K. and Benitez-Nelson, C.R. (2008) Cobalt, manganese, and iron near the Hawaiian Islands: A potential concentrating mechanism for cobalt within a cyclonic eddy and implications for the hybrid-type trace metals. Deep-Sea Res. II 55, 1473-1490.

Nozaki, Y., Thomson, J. and Turekian, K.K. (1976) The distribution of $210 \mathrm{~Pb}$ and $210 \mathrm{Po}$ in the surface waters of the Pacific Ocean. Earth Planet. Sci. Lett. 32, 304-312.

Nozaki, Y., Zhang, J. and Takeda, A. (1997) 2I0Pb and210Po in the equatorial Pacific and the Bering Sea: the effects of biological productivity and boundary scavenging. Deep-Sea Res. II 44, 2203-2220.

Oguri, K., Kawamura, K., Sakaguchi, A., Toyofuku, T., Kasaya, T., Murayama, M., Fujikura, K., Glud, R.N. and Kitazato, H. (2013) Hadal disturbance in the Japan Trench induced by the 2011 Tohoku-Oki Earthquake. Sci. Rep. 3, 1915.

Okubo, A., Takeda, S. and Obata, H. (2013) Atmospheric deposition of trace metals to the western North Pacific Ocean observed at coastal station in Japan. Atmospheric Res. 129-130, 20-32.

Orians, K.J. and Bruland, K.W. (1985) Dissolved aluminium in the central North Pacific. Nature 316, 427-429.

Orians, K.J. and Bruland, K.W. (1986) The biogeochemistry of aluminum in the Pacific Ocean. Earth Planet. Sci. Lett. 78, 397-410. 
1027

1028

1029

1030

1031

1032

1033

1034

1035

1036

1037

1038

1039

1040

1041

1042

1043

1044

1045

1046

1047

1048

1049

1050

1051

1052

1053

1054

1055

1056

1057

1058

1059

1060

1061

1062

1063

1064

1065

Pinedo-González, P., West, A.J., Tovar-Sanchez, A., Duarte, C.M. and Sañudo-Wilhelmy, S.A. (2018) Concentration and isotopic composition of dissolved $\mathrm{Pb}$ in surface waters of the modern global ocean. Geochim. Cosmochim. Acta 235, 41-54.

Rahn, K.A. (1976) Silicon and aluminum in atmospheric aerosols: Crust-air fractionation? Atmospheric Environ. 10, 597-601.

Rigaud, S., Stewart, G., Baskaran, M., Marsan, D. and Church, T. (2015) 210Po and 210Pb distribution, dissolved-particulate exchange rates, and particulate export along the North Atlantic US GEOTRACES GA03 section. Deep-Sea Res. II 116, 60-78.

Rolison, J.M., Middag, R., Stirling, C.H., Rijkenberg, M.J.A. and de Baar, H.J.W. (2015)

Zonal distribution of dissolved aluminium in the Mediterranean Sea. Mar. Chem. 177, Part 1, 87-100.

Rudnick, R.L. and Gao, S. (2005) Composition of the continental crust, in: Rudnick, R.L. (Ed.), The Crust. Elsevier-Pergamon, Oxford, pp. 1-64.

Rusiecka, D., et al. (2018) Anthropogenic Signatures of Lead in the Northeast Atlantic. Geophys. Res. Lett. 45, 2734-2743.

Saito, M.A. and Moffett, J.W. (2001) Complexation of cobalt by natural organic ligands in the Sargasso Sea as determined by a new high-sensitivity electrochemical cobalt speciation method suitable for open ocean work. Mar. Chem. 75, 49-68.

Saito, M.A., et al. (2017) The acceleration of dissolved cobalt's ecological stoichiometry due to biological uptake, remineralization, and scavenging in the Atlantic Ocean. Biogeosciences 14, 4637-4662.

Schaule, B.K. and Patterson, C.C. (1981) Lead concentrations in the northeast Pacific: evidence for global anthropogenic perturbations. Earth Planet. Sci. Lett. 54, 97-116.

Schlitzer, R. (2018) Ocean Data View. https://odv.awi.de.

Schlitzer, R., et al. (2018) The GEOTRACES Intermediate Data Product 2017. Chem. Geol. 493, 210-223.

Seyfried Jr, W.E., Seewald, J.S., Berndt, M.E., Ding, K. and Foustoukos, D.I. (2003) Chemistry of hydrothermal vent fluids from the Main Endeavour Field, northern Juan de Fuca Ridge: Geochemical controls in the aftermath of June 1999 seismic events. J. Geophys. Res.: Solid Earth 108, 2429.

Shelley, R.U., Zachhuber, B., Sedwick, P.N., Worsfold, P.J. and Lohan, M.C. (2010) Determination of total dissolved cobalt in UV-irradiated seawater using flow injection with chemiluminescence detection. Limnol. Oceanogr.: Methods 8, 352-362.

Slemons, L., Paul, B., Resing, J. and Murray, J.W. (2012) Particulate iron, aluminum, and manganese in the Pacific equatorial undercurrent and low latitude western boundary current sources. Mar. Chem. 142-144, 54-67.

Smith, J.N., Rossi, V., Buesseler, K.O., Cullen, J.T., Cornett, J., Nelson, R., Macdonald, A.M., Robert, M. and Kellogg, J. (2017) Recent Transport History of Fukushima Radioactivity in the Northeast Pacific Ocean. Environ. Sci. Technol. 51, 10494-10502. 
1066

1067

1068

1069

1070

1071

1072

1073

1074

1075

1076

1077

1078

1079

1080

1081

1082

1083

1084

1085

1086

1087

1088

1089

1090

1091

1092

1093

1094

1095

1096

1097

1098

1099

1100

1101

1102

1103

1104

Sohrin, Y. and Bruland, K.W. (2011) Global status of trace elements in the ocean. Trends Anal. Chem. 30, 1291-1307.

Sunda, W.G. and Huntsman, S.A. (1988) Effect of sunlight on redox cycles of manganese in the southwestern Sargasso Sea. Deep-Sea Res. A 35, 1297-1317.

Talley, L.D., Pickard, G.L., Emery, W.J. and Swift, J.H. (2011) Descriptive Physical Oceanography: An Introduction, 6th ed. Elsevier, Amsterdam.

Thunell, R., Tappa, E., Varela, R., Llano, M., Astor, Y., Muller-Karger, F. and Bohrer, R. (1999) Increased marine sediment suspension and fluxes following an earthquake. Nature 398, 233-236.

van Hulten, M., Middag, R., Dutay, J.C., de Baar, H., Roy-Barman, M., Gehlen, M., Tagliabue, A. and Sterl, A. (2017) Manganese in the west Atlantic Ocean in the context of the first global ocean circulation model of manganese. Biogeosciences 14, 1123-1152.

Von Damm, K.L. and Bischoff, J.L. (1987) Chemistry of hydrothermal solutions from the southern Juan de Fuca Ridge. J. Geophys. Res.: Solid Earth 92, 11334-11346.

$\mathrm{Vu}$, H.T.D. and Sohrin, Y. (2013) Diverse stoichiometry of dissolved trace metals in the Indian Ocean. Sci. Rep. 3, 1745.

Wu, J., Rember, R., Jin, M., Boyle, E.A. and Flegal, A.R. (2010) Isotopic evidence for the source of lead in the North Pacific abyssal water. Geochim. Cosmochim. Acta 74, 4629-4638.

Wuttig, K., et al. (2019) Critical evaluation of a seaFAST system for the analysis of trace metals in marine samples. Talanta 197, 653-668.

Wyrtki, K. and Kilonsky, B. (1984) Mean Water and Current Structure during the Hawaii-to-Tahiti Shuttle Experiment. J. Phys. Oceanogr. 14, 242-254.

Yang, L., et al. (2018) Inter-laboratory study for the certification of trace elements in seawater certified reference materials NASS-7 and CASS-6. Anal. Bioanal. Chem. 410, 4469-4479.

Yasuda, I. (1997) The origin of the North Pacific Intermediate Water. J. Geophys. Res.: Oceans 102, 893-909.

Yasuda, I. (2003) Hydrographic Structure and Variability in the Kuroshio-Oyashio Transition Area. J. Oceanogr. 59, 389-402.

Zheng, L., Minami, T., Takano, S., Minami, H. and Sohrin, Y. (2017) Distribution and stoichiometry of $\mathrm{Al}, \mathrm{Mn}, \mathrm{Fe}, \mathrm{Co}, \mathrm{Ni}, \mathrm{Cu}, \mathrm{Zn}, \mathrm{Cd}$, and $\mathrm{Pb}$ in seawater around the Juan de Fuca Ridge. J. Oceanogr. 73, 669-685.

Zurbrick, C.M., et al. (2018) Dissolved Pb and Pb isotopes in the North Atlantic from the GEOVIDE transect (GEOTRACES GA-01) and their decadal evolution. Biogeosciences 15, 4995-5014.

Zurbrick, C.M., Gallon, C. and Flegal, A.R. (2017) Historic and Industrial Lead within the Northwest Pacific Ocean Evidenced by Lead Isotopes in Seawater. Environ. Sci. Technol. 51, 1203-1212. 
Table 1

Statistical summary of seawater data.

\begin{tabular}{|c|c|c|c|c|c|c|c|c|}
\hline \multirow{2}{*}{ Element } & \multirow{2}{*}{ Fraction } & \multicolumn{4}{|r|}{$n$} & \multirow{2}{*}{ Minimum } & \multirow{2}{*}{ Maximum } & \multirow{2}{*}{ Median } \\
\hline & & Total & $>\mathrm{DL}$ & $<\mathrm{DL}$ & Questionable and discarded & & & \\
\hline \multirow{3}{*}{$\mathrm{Al}(\mathrm{nmol} / \mathrm{kg})$} & td & 638 & 610 & 21 & 7 & $<0.1$ & 59.6 & 2.16 \\
\hline & $\mathrm{d}$ & 638 & 438 & 76 & 124 & $<0.1$ & 8.63 & 0.46 \\
\hline & $\operatorname{lp}$ & 638 & 436 & 75 & 127 & $<0.2$ & 56.7 & 1.13 \\
\hline \multirow{3}{*}{$\mathrm{Mn}(\mathrm{nmol} / \mathrm{kg})$} & td & 638 & 633 & 0 & 5 & 0.17 & 12.3 & 0.74 \\
\hline & $\mathrm{d}$ & 638 & 633 & 0 & 5 & 0.08 & 8.38 & 0.52 \\
\hline & $\mathrm{lp}$ & 638 & 429 & 199 & 10 & $<0.1$ & 5.65 & 0.12 \\
\hline \multirow{3}{*}{ Co (pmol/kg) } & $\mathrm{td}$ & 638 & 631 & 0 & 7 & 4.5 & 221 & 24.1 \\
\hline & $\mathrm{d}$ & 638 & 623 & 3 & 12 & $<0.4$ & 179 & 20.2 \\
\hline & $\mathrm{lp}$ & 638 & 288 & 332 & 18 & $<4$ & 44.2 & $<4$ \\
\hline \multirow{3}{*}{$\mathrm{Pb}(\mathrm{pmol} / \mathrm{kg})$} & $\mathrm{td}$ & 638 & 628 & 0 & 10 & 3.4 & 89.7 & 28.5 \\
\hline & $\mathrm{d}$ & 638 & 579 & 0 & 59 & 2.0 & 85.0 & 28.6 \\
\hline & $\mathrm{lp}$ & 638 & 30 & 545 & 63 & $<4$ & 14.1 & $<4$ \\
\hline
\end{tabular}


Table 2

Summary of water mass data.

\begin{tabular}{|c|c|c|c|c|c|c|c|c|c|c|c|c|c|c|c|c|}
\hline \multirow{2}{*}{ Water mass } & \multirow{2}{*}{ Salinity } & \multirow{2}{*}{$\begin{array}{c}\text { Potential } \\
\text { Temperatur } \\
\text { e }\left[{ }^{\circ} \mathrm{C}\right] \\
\end{array}$} & \multirow{2}{*}{$\sigma_{\theta}\left[\mathrm{kg} / \mathrm{m}^{3}\right]$} & \multirow{2}{*}{ Reference } & \multicolumn{3}{|c|}{$\mathrm{Al}[\mathrm{nmol} / \mathrm{kg}]$} & \multicolumn{3}{|c|}{$\mathrm{Mn}[\mathrm{nmol} / \mathrm{kg}]$} & \multicolumn{3}{|c|}{ Co $[\mathrm{pmol} / \mathrm{kg}]$} & \multicolumn{3}{|c|}{$\mathrm{Pb}[\mathrm{pmol} / \mathrm{kg}]$} \\
\hline & & & & & $\mathrm{td}$ & $\mathrm{d}$ & $1 \mathrm{p}$ & $\mathrm{td}$ & $\mathrm{d}$ & $1 \mathrm{p}$ & $\mathrm{td}$ & d & lp & td & d & lp \\
\hline $\begin{array}{l}\text { Subtropical Mode Water } \\
\text { (STMW) }\end{array}$ & & & $25.2-25.8$ & Yasuda 2003 & $0.12-1.3$ & $<0.1-1.3$ & $<0.2-1.0$ & $0.54-1.2$ & $0.45-0.79$ & $<0.1-0.11$ & $15-31$ & $8-25$ & $<4-13$ & $64-78$ & $62-83$ & $<4$ \\
\hline $\begin{array}{l}\text { Central Mode Water } \\
\text { (CMW) }\end{array}$ & & & $26.0-26.7$ & Yasuda 2003 & $0.54-4.9$ & $<0.1-1.6$ & $0.21-1.3$ & $0.27-1.1$ & $0.19-0.95$ & $<0.1-0.35$ & $28-43$ & $26-39$ & $<4-10$ & $52-80$ & $56-83$ & $<4$ \\
\hline $\begin{array}{l}\text { Okhotsk Sea Mode } \\
\text { Water (OSMW) }\end{array}$ & $33.5-33.6$ & $1-2$ & $26.6-27$ & Yasuda 1997 & $1.6-6.0$ & $0.21-0.53$ & $1.4-5.5$ & $1.2-2.0$ & $0.51-1.7$ & $0.27-0.91$ & $48-75$ & $50-72$ & $<4-7$ & $31-52$ & $30-51$ & $<4$ \\
\hline $\begin{array}{l}\text { North Pacific } \\
\text { Intermediate Water } \\
\text { (NPIW) }\end{array}$ & $33.8-34.1$ & & $\begin{array}{c}26.4-27.2, \\
\text { averaging } \\
26.8\end{array}$ & $\begin{array}{l}\text { Dickson et al. } \\
\text { 2000, Bostock } \\
\text { et al. } 2010\end{array}$ & $1.0-6.8$ & $0.18-1.1$ & $0.63-6.1$ & $0.32-1.1$ & $0.22-0.74$ & $<0.1-0.37$ & $34-47$ & $30-43$ & $<4-9$ & 44-71 & $41-63$ & $<4-6$ \\
\hline $\begin{array}{l}\text { Equatorial Pacific } \\
\text { Intermediate Water } \\
\text { (EqPIW) }\end{array}$ & $34.5-34.6$ & & 27.3 & $\begin{array}{l}\text { Bostock et al. } \\
2010\end{array}$ & $1.1-2.5$ & $0.87-1.9$ & $<0.2-1.6$ & $0.32-0.43$ & $0.22-0.36$ & $<0.1-0.14$ & $32-39$ & $30-38$ & $<4$ & $12-25$ & $12-28$ & $<4$ \\
\hline $\begin{array}{l}\text { Upper Circumpolar } \\
\text { Deep Water (UCDW) }\end{array}$ & 34.6 & 2.5 & 27.6 & $\begin{array}{l}\text { Talley et al. } \\
2012\end{array}$ & $1.2-3.0$ & $0.73-1.6$ & $<0.2-1.2$ & $0.22-0.38$ & $0.17-0.23$ & $<0.1-0.16$ & $21-30$ & $17-29$ & $<4$ & $7-12$ & $9-14$ & $<4$ \\
\hline $\begin{array}{l}\text { Pacific Deep Water } \\
\text { (PDW) }\end{array}$ & 34.7 & $1.1-1.2$ & 27.7 & $\begin{array}{l}\text { Talley et al. } \\
2011\end{array}$ & $0.88-4.5$ & $<0.1-0.86$ & $0.63-3.7$ & $0.19-0.82$ & $0.13-0.66$ & $<0.1-0.33$ & $14-26$ & $13-23$ & $<4-6$ & $9-31$ & $6-32$ & $<4-6$ \\
\hline $\begin{array}{l}\text { Lower Circumpolar } \\
\text { Deep Water (LCDW) }\end{array}$ & 34.7 & $1-2$ & 27.8 & $\begin{array}{c}\text { Talley et al. } \\
2013\end{array}$ & $1.5-40$ & $0.36-4.1$ & $0.60-37$ & $0.16-5.7$ & $0.08-1.3$ & $<0.1-4.4$ & $12-32$ & $8-20$ & $<4-20$ & $3-16$ & $3-16$ & $<4-6$ \\
\hline
\end{tabular}




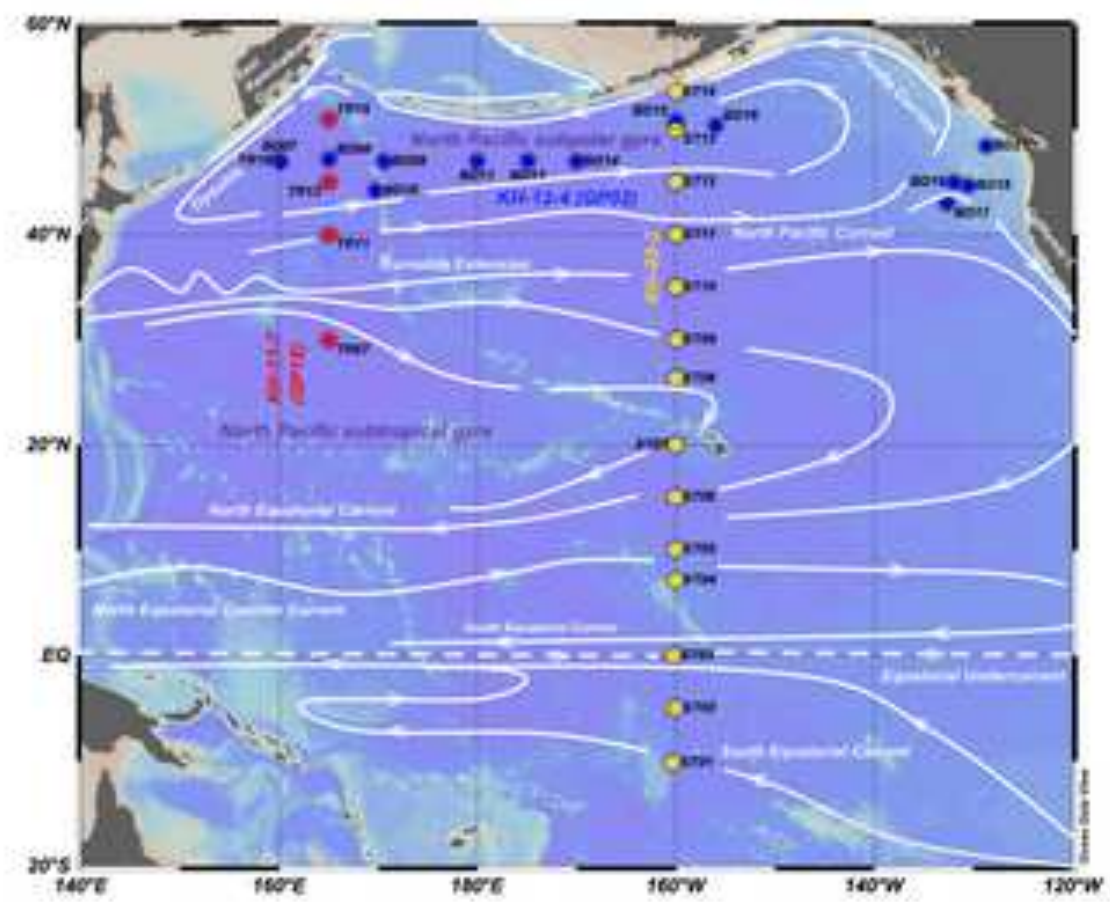

(1)

\section{Figure 1}




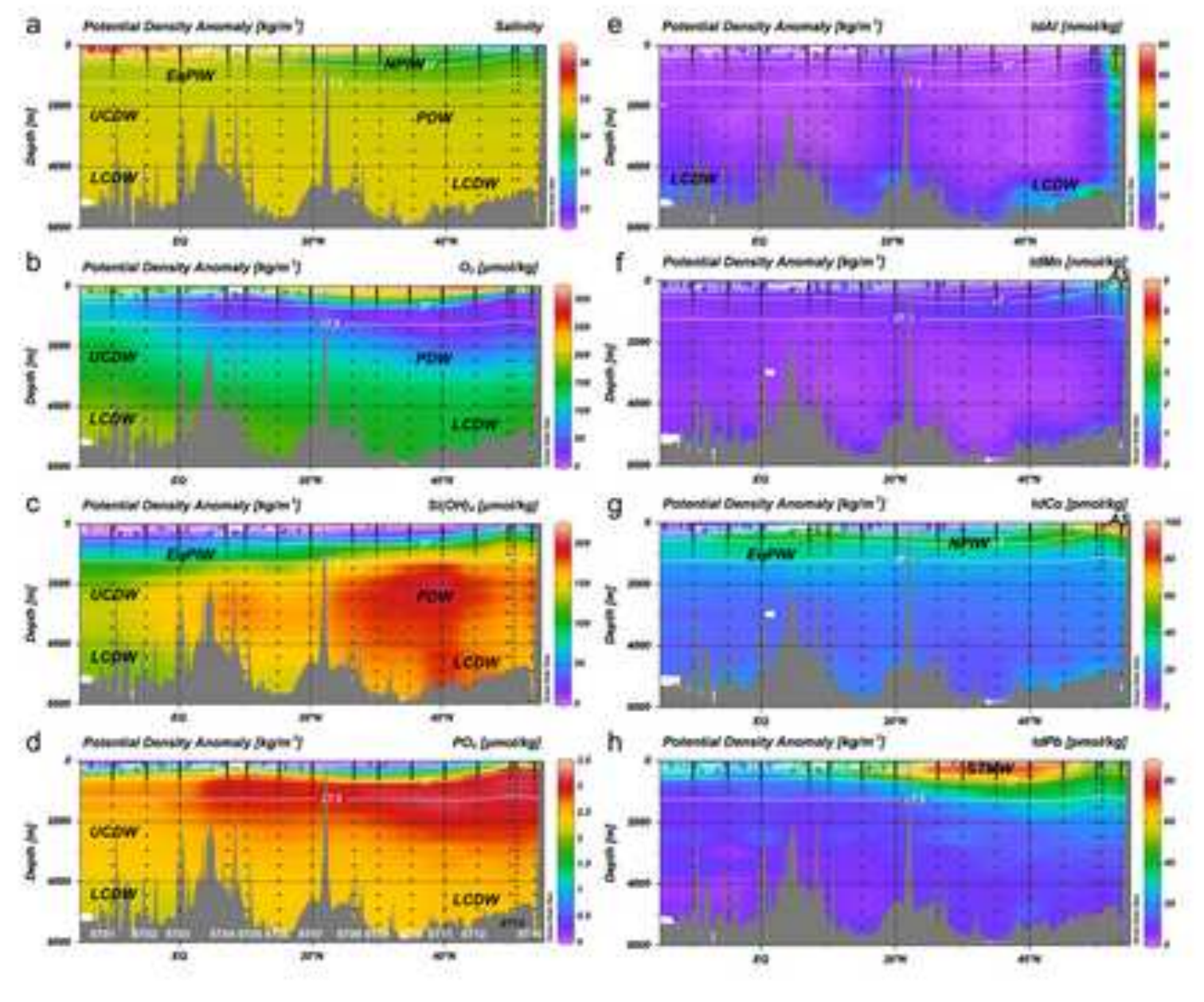

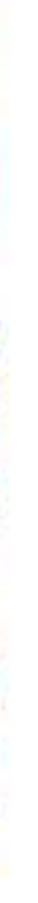

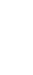




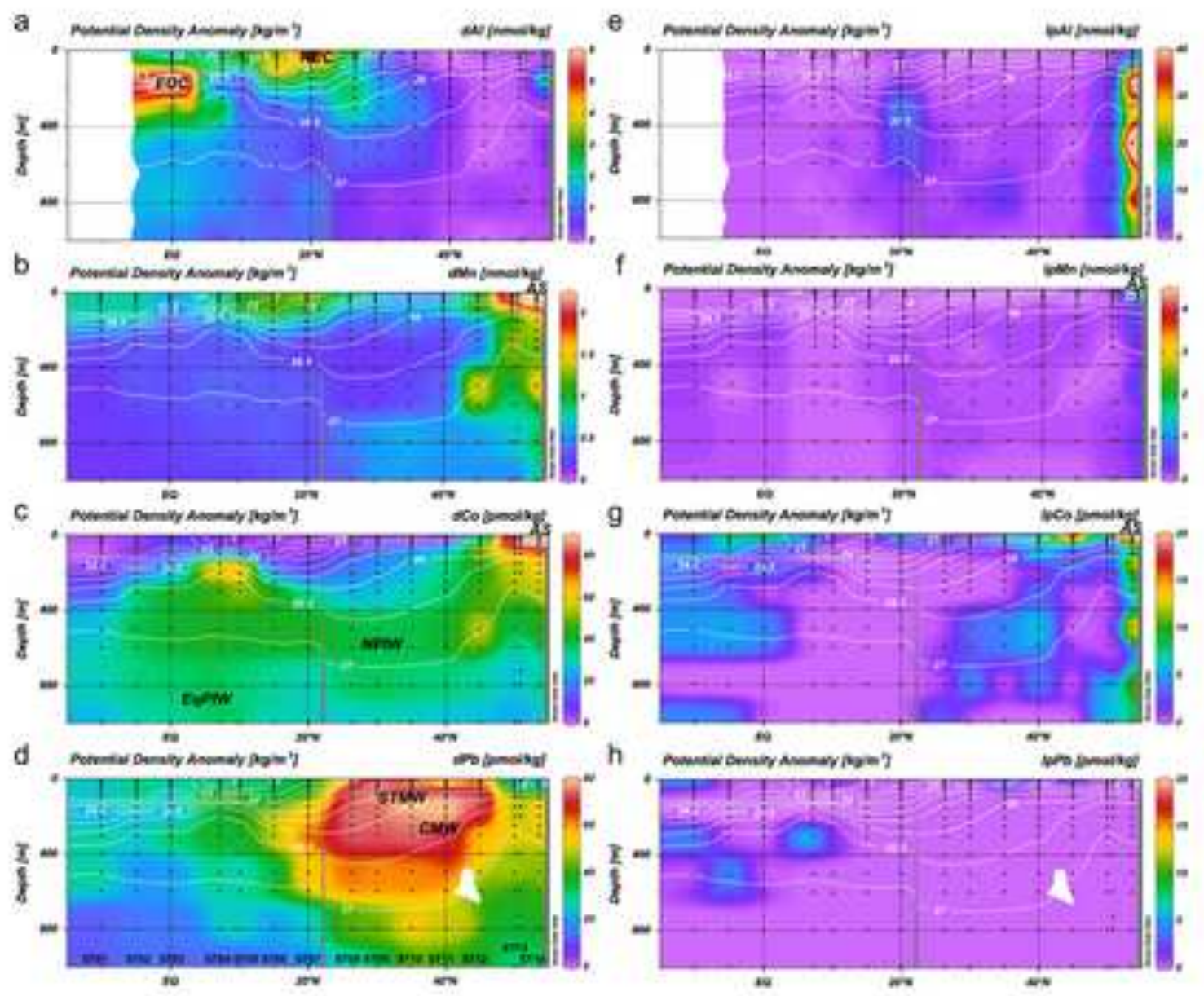

Figure 3 

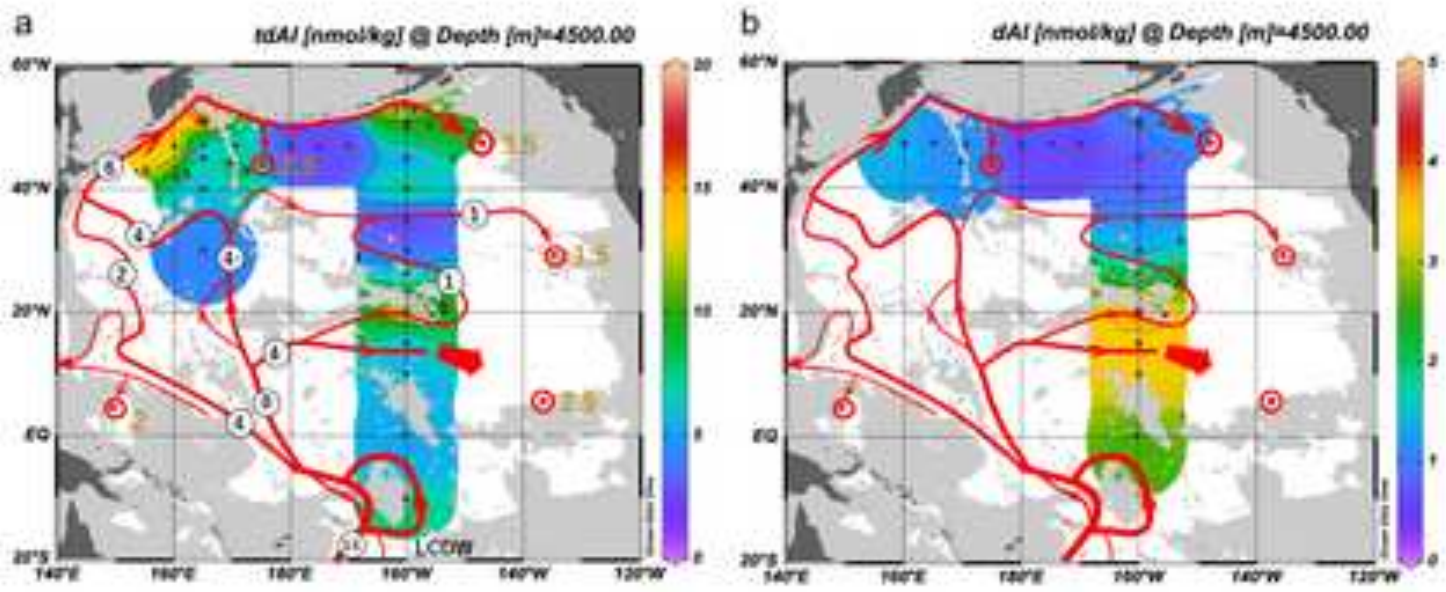

Figure 4 
些京都大学

C a

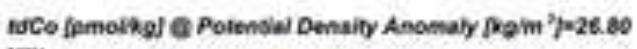

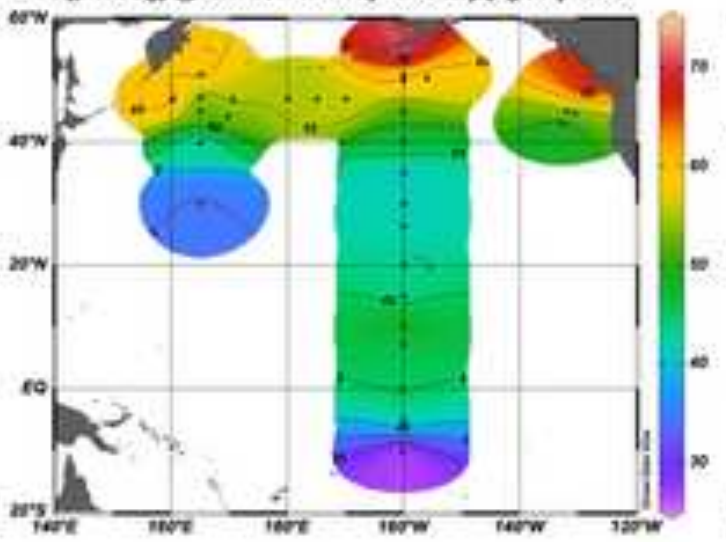

b

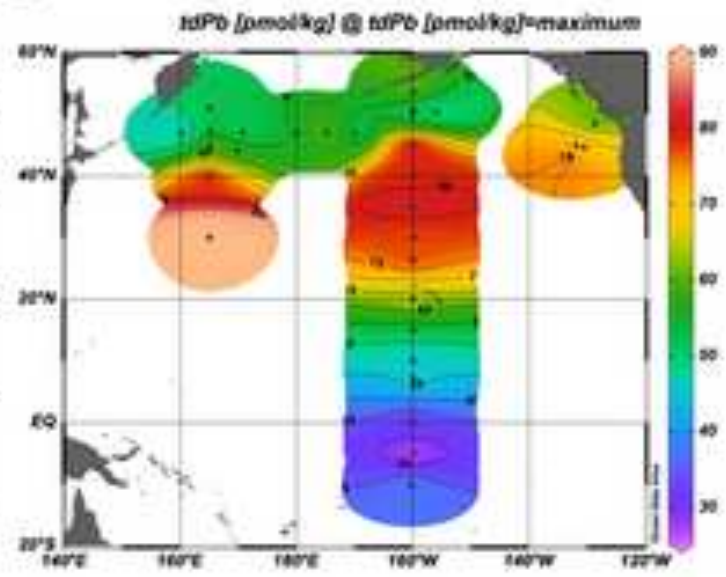

Figure 5 


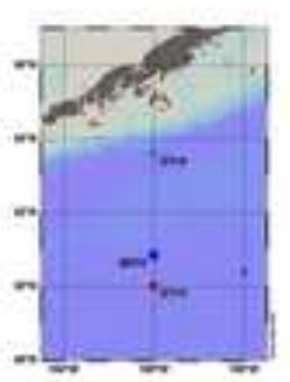

a

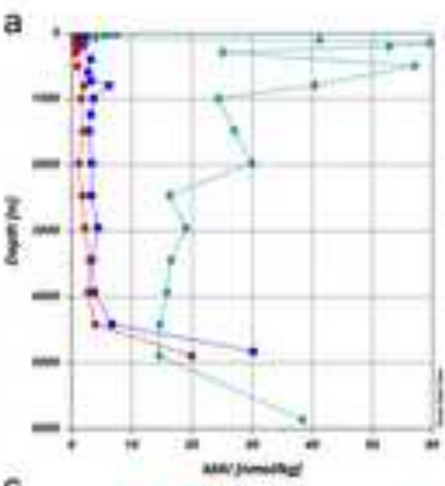

c.

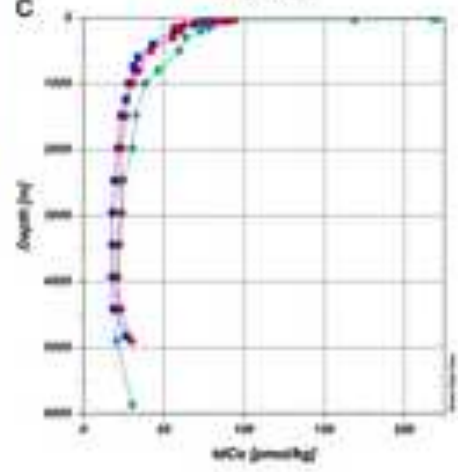

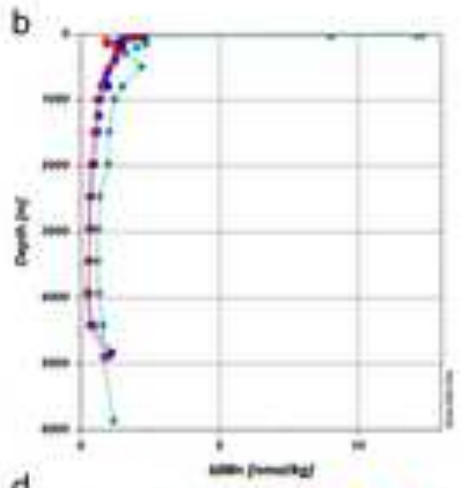

d

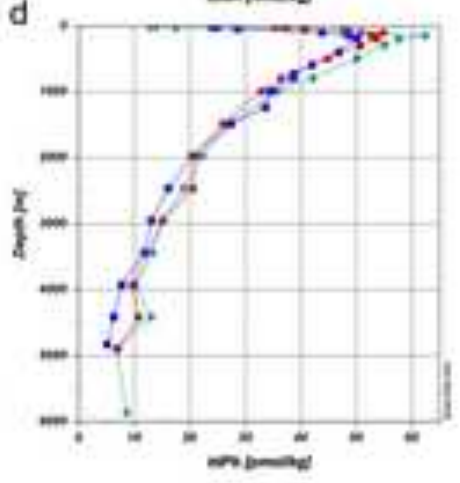




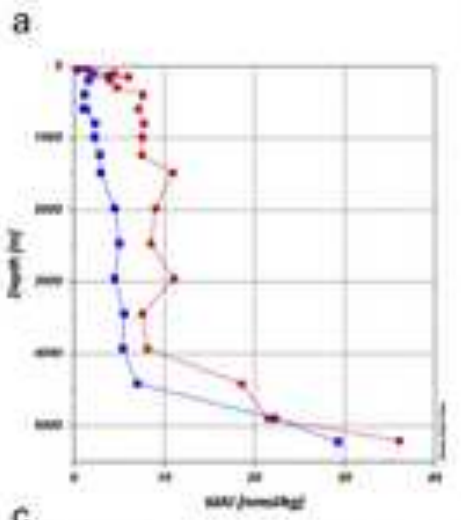

b
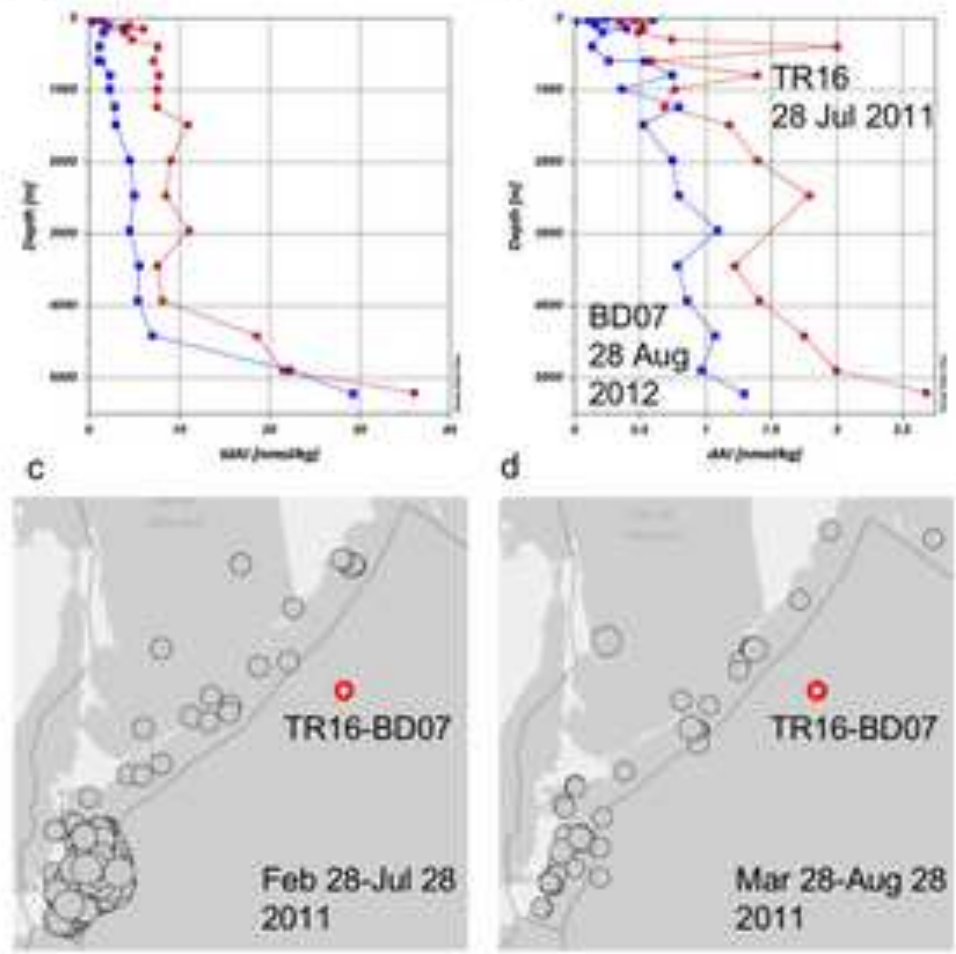

。

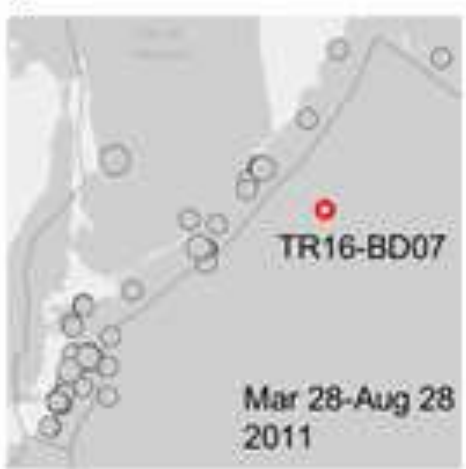

Figure 7 

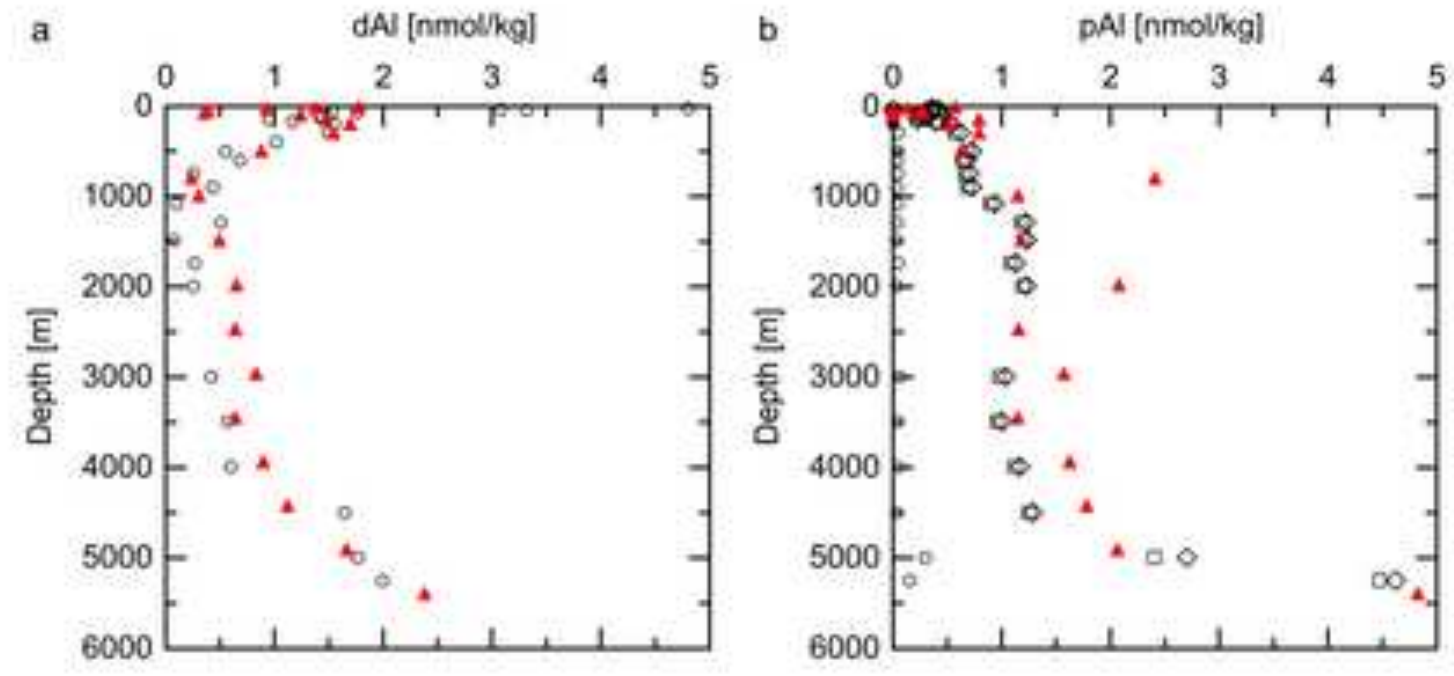

Figure 8 

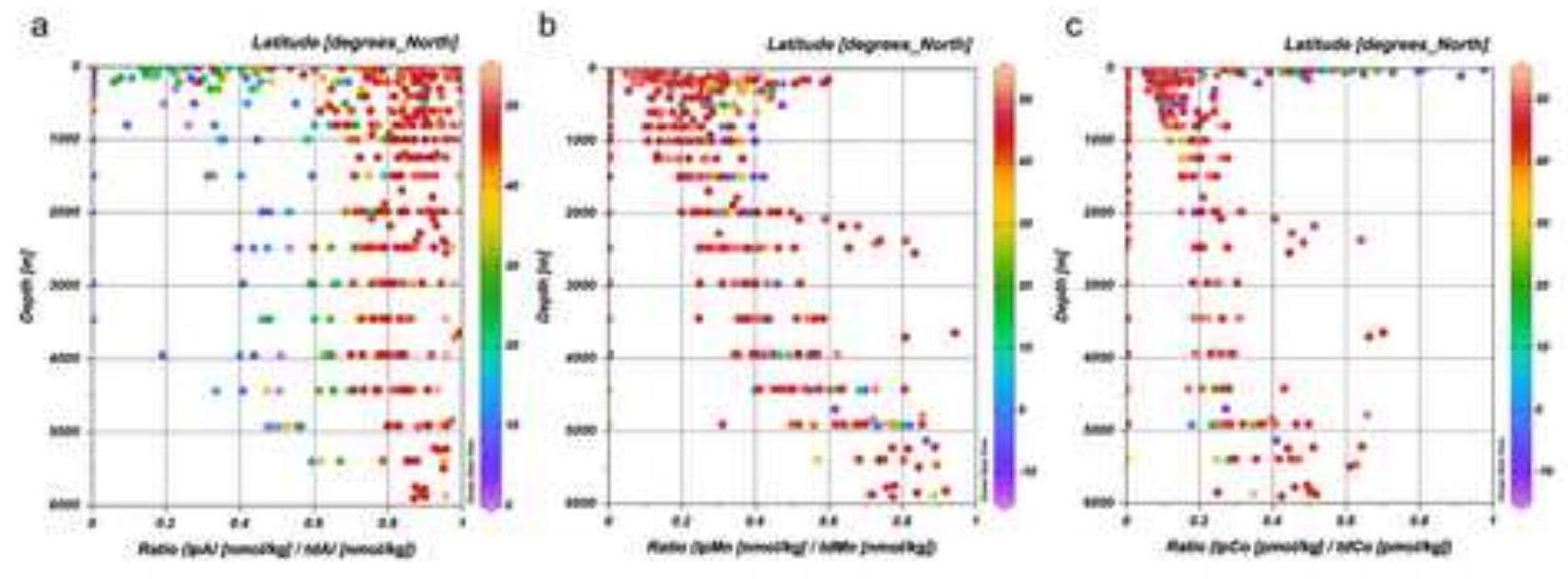

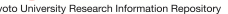

\section{Figure 9}




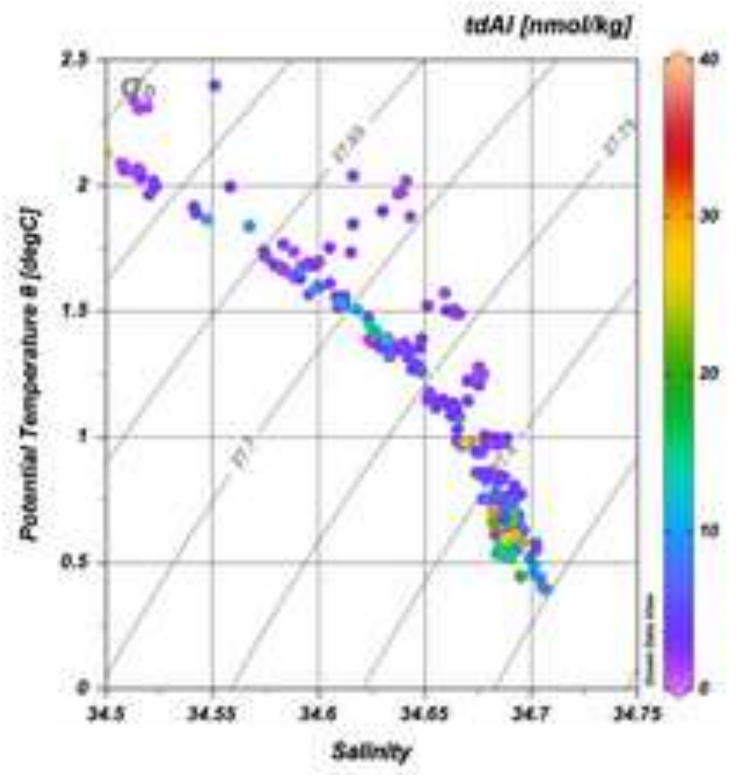

Figure 10 

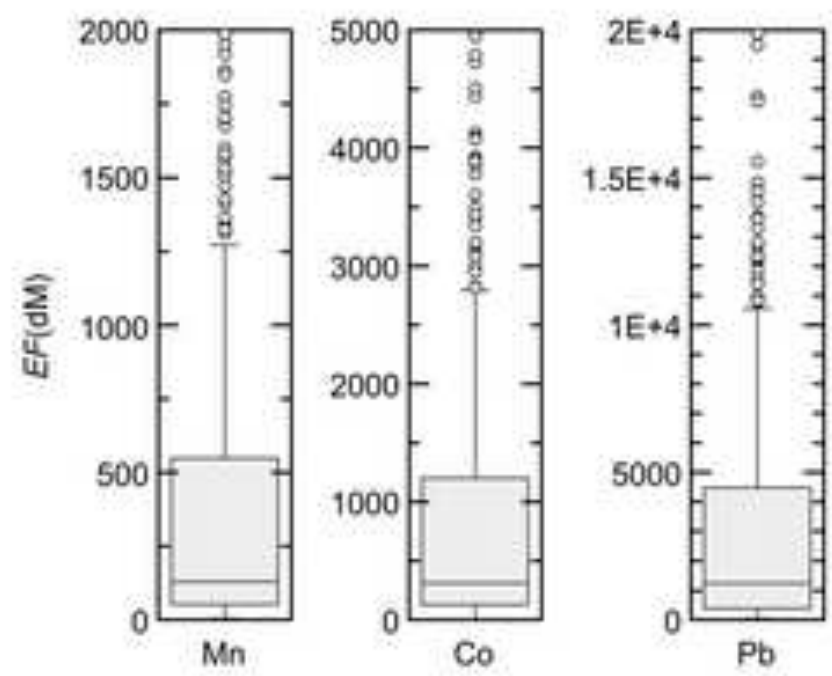

Figure 11 


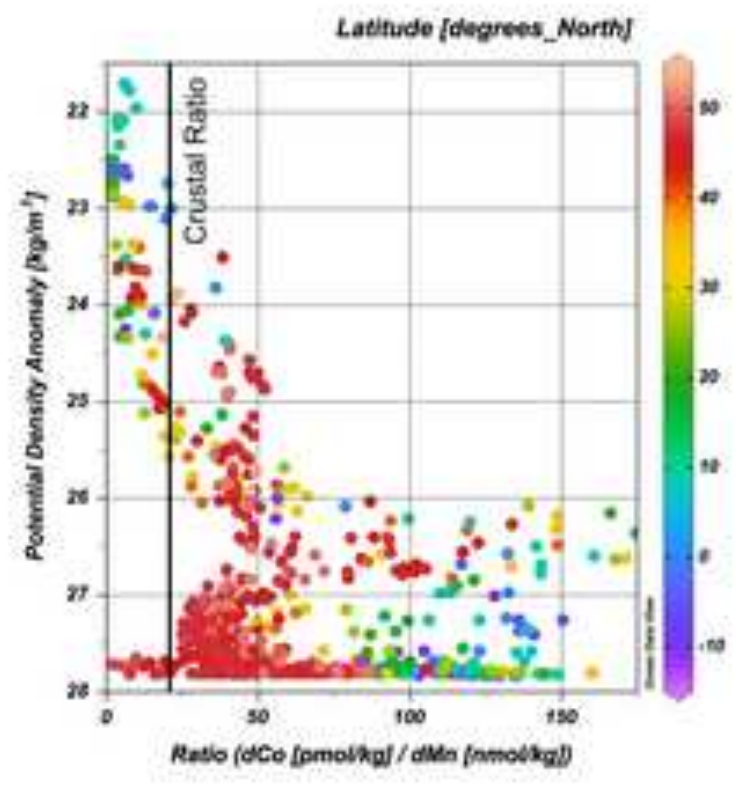

Figure 12 


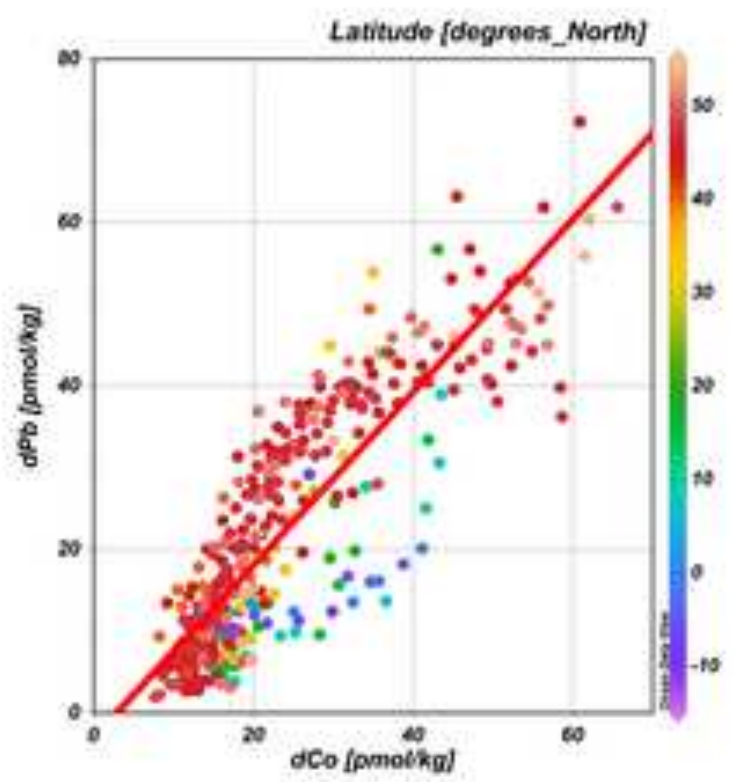

\section{Figure 13}


(20)

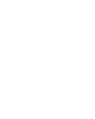

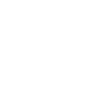

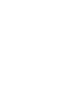

(1)

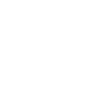

$\sqrt{20}$

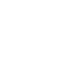

$\sqrt{20}$

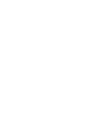

(1) 
